This is the final pre-publication version of:

Cashman M.J., Pilotto F., Harvey G.L., Wharton G. and Pusch M.T. (2016) Combined stable isotope and fatty acid analyses demonstrate that large wood increases the autochthonous trophic base of a macroinvertebrate assemblage. Freshwater Biology. DOI: 10.1111/fwb.12727

\title{
Combined stable isotope and fatty acid analyses demonstrate that large wood increases the autochthonous trophic base of a macroinvertebrate assemblage
}

Matthew J. Cashman ${ }^{\star 1,2,3}$, Francesca Pilotto ${ }^{\star 1,2,3}$, Gemma L. Harvey ${ }^{3}$, Geraldene Wharton ${ }^{3}$, Martin T. Pusch

${ }^{1}$ Leibniz Institute of Freshwater Ecology and Inland Fisheries (IGB), Berlin, Germany

${ }^{2}$ Institute of Biology, Freie Universität Berlin, Berlin, Germany

${ }^{3}$ School of Geography, Queen Mary University of London, London, U.K.

* Co-first authorship: MJC and FP equally contributed to the study

Email address: matthewjcashman@gmail.com

Running Header: Large wood increases the autochthonous trophic base

Keywords: macroinvertebrates, trophic resources, lake-river coupling, sand-bed river, food webs 


\section{Summary}

1. Large wood (LW), defined as pieces of wood greater than $10 \mathrm{~cm}$ in diameter and $1 \mathrm{~m}$ long, is well known to alter river hydromorphology and the availability of potential food resources for consumers. However, there has been a lack of studies investigating whether these can cause shifts in the trophic base, which may explain alterations to the total abundance and taxonomic structure of the macroinvertebrate assemblage.

2. We aimed to determine how the presence of large wood altered the trophic base of the macroinvertebrate consumer assemblage in a lowland river, and to provide a methodological comparison of two assimilation-based food web methods: stable isotope analysis (SIA) and fatty acid biomarker profiles (FA). To do so, we quantified the contribution of trophic resources to the diets of macroinvertebrates colonizing the surface of LW, present in this study as single logs, and surrounding bed sediments with those from bed sediments of a nearby control site with minimal amounts of LW.

3. SIA showed that the macroinvertebrate food web, even for non-filter feeding taxa, was mostly sustained by seston exported from a lake $1 \mathrm{~km}$ upstream, highlighting a high degree of lake-river coupling. The presence of wood altered the trophic base from being predominantly seston-supported to one with increased support from epixylic autochthonous production (i.e. periphyton and bryophytes on wood). Terrestrial matter (i.e. leaves and grass) and organic sediments were a relatively unimportant fraction of the trophic base $(<10 \%)$ in all locations.

4. FA did not directly track the influence of seston, but instead differentiated between overall allochthonous (terrestrial) and autochthonous (aquatic) components of the trophic base. In particular, FA analysis demonstrated the higher nutritional value of autochthonous primary producers, and provided supporting evidence that most consumers, even seston-feeders, were primarily supported by autochthonous resources and not by allochthonous matter. FA indicated shifts in some taxa-specific diets not detected by stable isotopes alone.

5. Our study demonstrated that the combined use of stable isotopes and fatty acids provides new insights into determining the trophic base of a complex food web with trophic 
resources of both terrestrial/aquatic and lacustrine/riverine origins. In addition, directly comparing results from both stable isotope and fatty acid analyses provided additional information on selective feeding by seston-feeding taxa on autochthonous and allochthonous fractions of the seston.

6. The presence of large wood in the river channel decreased lake-river coupling by providing alternative basal resources, primarily through increasing high quality autochthonous production on wood and by providing a superior substratum for net-spinning caddisflies to feed on a fraction of the seston richer in essential fatty acids. River management strategies that incorporate instream large wood therefore have the potential to alter energy flows and enhance ecosystem productivity by increasing the quantity and quality of available basal food resources. 


\section{Introduction}

2 Large wood (LW), usually defined as wood pieces in the river channel larger than $10 \mathrm{~cm}$ in

3 diameter and $1 \mathrm{~m}$ in length (Gippel et al., 1996) and often referring to whole logs fallen into or

4 across a stream channel (Gurnell et al., 2002; Gurnell et al., 2000; Reeves, Burnett \& McGarry,

5 2003), constitutes a fundamental component in the health and integrity of river ecosystems. LW

6 functions as an element of structural complexity in the channel, increasing the heterogeneity of

7 physical habitat conditions (Ehrman \& Lamberti, 1992; Gregory, Gurnell \& Petts, 1995;

8 Montgomery et al., 1995; Gurnell \& Linstead, 1998). LW has been shown to increase

9 macroinvertebrate assemblage diversity by providing a stable and hard substratum for colonisation

10 (Hoffmann \& Hering, 2000; Benke \& Wallace, 2003; Schröder et al., 2013) and by providing

11 diverse habitats in nearby river-bed sediments (Pilotto et al., 2014). Large wood may also

12 influence the local abundance and composition of consumers by affecting the availability and

13 quality of heterogeneous food resources. LW can serve directly as a food source for xylophilic

14 macroinvertebrate species, but the proportion of these taxa is relatively low (Anderson et al., 1978;

15 Anderson, Steedman \& Dudley, 1984; Anderson, 1989; Hoffman \& Hering, 2000). LW may also

16 alter the availability of both allochthonous (terrestrial) and autochthonous (aquatic) food resources

17 present in the channel. Much research has focused on the ability of LW to increase organic matter

18 retention by trapping fine sediment, leaves, twigs and other transported matter (Bilby \& Likens,

19 1980; Bilby, 1981). In addition, the erosion and decay of the wood surface can contribute to

20 increased organic matter within the reach (Ward \& Aumen, 1986). LW also directly increases the

21 total surface area of hard substratum for colonisation by biofilm (Hax \& Golladay, 1993; Wondzell

22 \& Bisson, 2003), and the rough surface texture of wood can result in increased algal diversity and

23 unique species assemblages, particularly for taxa sensitive to shear stress (Sabater, Gregory \&

24 Sedell, 1998). This may be particularly important in sand-bed rivers, as stable and hard substrata

25 besides LW may be otherwise limited in the channel. However, few studies have directly

26 investigated whether these changes to food availability shift the trophic base of the

27 macroinvertebrate assemblage. 
Stream ecosystems with dense riparian shading have been hypothesised to be primarily supported by allochthonous production due to light-limitation of in-stream production and high inputs of terrestrial matter (Vannote et al., 1980; Smock, Metzler \& Gladden, 1989). However, recent work on the trophic base of macroinvertebrate assemblages have suggested that terrestrial matter may contribute a relatively minor fraction of the diet, with macroinvertebrates largely dependent on autochthonous matter, even for species generally considered shredders (Torres-Ruiz, Wehr \&

Perrone, 2007; Lau, Leung \& Dudgeon, 2009). Allochthonous carbon is mostly recalcitrant, while autochthonous production, although less plentiful, is more labile and contains higher concentrations of nitrogen, phosphorus and specifically highly unsaturated fatty acids (HUFAs)(Brett \& Müller-Navarra, 1997; Thorp \& Delong, 2002; Torres-Ruiz, Wehr \& Perrone, 2007). A high-quality food base rich in HUFAs is suggested to enhance energy transfer from basal resources to consumers, whereas a lack of these important components may lead to trophic decoupling, whereby increased primary production does not result in increased production at higher trophic levels (Brett \& Müller-Navarra, 1997; Müller-Navarra et al., 2000; Gladyshev et al., 2011; Perhar, Arhonditsis \& Brett, 2013; Taipale et al., 2014). While the increased residence time of organic matter trapped by LW may increase microbial enrichment and the quality of allochthonous matter for the food web (Smock, Metzler \& Gladden, 1989; Fry \& Fuller, 1991), even limited increases in autochthonous production associated with LW may have large proportional effects on the trophic base of the macroinvertebrate assemblage.

Stable isotope analysis (SIA) of carbon and nitrogen retention and fractionation has become a standard method in evaluating aquatic food webs, with Bayesian mixing models providing quantitative estimates of mixed diet composition (Moore \& Semmens, 2008; Parnell et al., 2008; Ward et al., 2011; Parnell et al., 2013). Combining SIA results with fatty acid biomarker profiles can facilitate the interpretation of food web structure, particularly in situations where some of the basal resources have overlapping isotope signatures or in cases of mixed trophy (El-Sabaawi et al., 2009; Allan et al., 2010; Galloway et al., 2012). Rather than the two- or three-source signals $(\mathrm{C}, \mathrm{N}, \mathrm{S})$ used in traditional stable isotope analysis, FA profiles use more than a dozen fatty acids that are synthesized in biologically relevant amounts by particular phylogenetic lineages (e.g. 
bacteria, diatoms, green plants). These profiles are then retained in consumers and can be used to trace trophic relationships through the aquatic environment, even in cases of omnivory (Gladyshev, Arts \& Sushchik, 2009).

We aimed to quantify the effect of LW on the trophic base of a river ecosystem by combining analyses of stable isotope and fatty acid biomarker profiles of the macroinvertebrates and their potential trophic resources on and around LW compared to areas of the channel without wood. We hypothesised that the presence of LW would support the growth of epixylic biofilms that would result in increased autochthonous support in the average diet of the benthic invertebrate assemblage around wood.

\section{Methods}

\section{Study area}

Field work was carried out in April 2012 in the Płociczna River, a lowland, minimally-disturbed sand-bed river in the Drawienski National Park in Western Poland (Fig. 1). The Drawienski National Park is in the southern part of the Pomeranian Lake District, with a geology of early-glacial outwash plains and land cover of mixed coniferous plantation and hardwoods. The Płociczna runs for $51 \mathrm{~km}$ until its confluence with the Drawa River, and the dominant riparian vegetation consists of broad-leaved trees, mainly alder (Alnus sp.). We studied two forested reaches (bankfull width: 12-15 m; near-bankfull discharge: $1.4-1.5 \mathrm{~m}^{3} \mathrm{~s}^{-1}$ ), with varying levels of LW (Fig. S1) that were located downstream of Lake Sitno, a 67 ha $^{-1}$ eutrophic throughflow lake. The upstream reach (ca. $700 \mathrm{~m}$ from the lake outflow) had little in in-channel LW (nine small wood structures in $100 \mathrm{~m}$, with a total volume of $22.9 \mathrm{~m}^{3} \mathrm{ha}^{-1}$ of channel area, primarily bark and twigs; hereafter "wood-poor site"), while a downstream reach (ca. $1000 \mathrm{~m}$ from the lake outflow) had abundant in-channel LW (25 wood structures in $100 \mathrm{~m}$, with a total volume of $94.4 \mathrm{~m}^{3} \mathrm{ha}^{-1}$ of channel area; hereafter "wood-rich site"). Overall, LW pieces consisted of whole logs fallen into the stream channel, covered in bark, both with and without branches, and uniformly aligned perpendicular to channel flow. Due to the low gradient and limited stream power of the studied reach, there was no evidence of large wood having been transported or re-orientated by flow. 
84

Basal food resources were collected in three replicate samples from each site and included wood, grass, leaf litter, sediments, bryophytes, filamentous algae, periphyton collected on wood, periphyton collected on mussel shells, and transported organic matter (“TOM"). Leaf litter and grass were collected from the riparian zone. The top 5-cm of sediment (sand and organic matter deposits) were collected with a Perspex sediment core. Bryophytes were collected from both wood and on the river banks. The filamentous green alga, Cladophora sp., which was only found in the wood-rich reach, was collected from submerged pieces of wood and cleaned of organic matter and epiphytes under a 10x dissecting microscope in the laboratory. Periphyton on wood was also collected from submerged pieces of large wood, which was removed to the river bank and sampled using a toothbrush. In the wood-poor site, only small pieces of woody material (i.e. bark, small branches) were present, which were also sampled for periphyton. After periphyton was removed from the wood surface, wood fragments were broken and removed with a razor blade and screwdriver for the cleaned wood sample. Periphyton on mussels was collected in the wood-poor reach with a toothbrush, as mussels were the only other hard substratum available in the channel. All periphyton slurries were collected in vials and put on ice until return to the laboratory. TOM was collected mid-river with a $125 \mu \mathrm{m}$ phytoplankton net over 30 minutes at three equidistant points (upstream, mid-point and downstream) along $100 \mathrm{~m}$ of each reach. The isotopic signature of total seston was further inferred from the isotopic signature of bulk unionid mussel tissue ("unio-derived seston": Unio tumidus and Unio pictorum) collected from the two study sites; unionid mussels are often used as a time-integrated seston signature (Cabana \& Rasmussen, 1996; Atkinson et al., 2014), since unionids are long-lived sestonic filter feeders and thus their tissue is less sensitive to seasonal fluctuations in the values of carbon and nitrogen stable isotope ratios. All samples were brought to the laboratory, where they were washed under filtered water, cleaned under a microscope (20x) in order to remove animals and organic material, and prepared for stable isotope and fatty acid analyses. Periphyton and TOM slurries were filtered onto pre-ashed 25-mm Whatman® GF/F filters (Sigma Aldritch Chemie Gmbh, Munich, Germany) and leaves and grass were ground into a fine powder with a ball tissue grinder. 
Macroinvertebrates were collected in the wood-rich site from the LW surface (WW samples) and bed-sediment within $20 \mathrm{~cm}$ of LW (WS samples), and in the wood-poor site from the bed-sediment away from any wood (NW samples).

For analysis of the macroinvertebrate taxonomic composition we selected six replicate pieces of LW within the wood-rich-site. We collected one sample from the surface of each LW by brushing an area of $0.26 \mathrm{~m}^{2}$ into a hand net. We collected benthic samples from the sediment around each selected LW at three sampling points: one upstream, one downstream, and one lateral to the LW. We additionally collected six replicate benthic samples in the wood-poor site. Each benthic sample consisted of the pooled material from five Surber samplers (frame size: $23 \times 23 \mathrm{~cm}$, mesh size: 500 $\mu \mathrm{m}$; total sampled area of each sample: $0.26 \mathrm{~m}^{2}$ ). Samples were preserved in $70 \%$ ethanol, and in the laboratory animals were identified to species or genus. Taxa abundances from the three sampling points on the river-bed sediments surrounding the same LW (upstream, downstream and lateral) were averaged in order to obtain a composite sample for the area surrounding each of the six replicate LW.

We collected three additional replicate invertebrate samples from the LW surface (WW), three from the sediment surrounding LW (WS), and three from bed-sediment in the wood-poor site (NW) for isotopes and fatty acid analyses. The samples were sorted in the field and transported in filtered river water to the laboratory where they were identified under a 10x microscope and left for $24 \mathrm{~h}$ for gut clearance. When the number of animals sufficed, half of the sample of each taxon was processed for stable isotope analysis and half for fatty acid analysis (Table 1).

\section{Sample processing for stable isotope analysis}

Trophic resources and single (large animals: e.g. Odonata) or pooled (small animals: e.g.

Chironomidae) macroinvertebrate individuals belonging to the same taxon were dried separately at $60{ }^{\circ} \mathrm{C}$ for $48 \mathrm{~h}$, weighed and ground to a fine powder. Subsamples of $\sim 1 \mathrm{mg}$ for animals and from 1 to $30 \mathrm{mg}$ for food resources were placed in tin capsules and sent for analysis at the UC Davis 
Stable Isotope Facility, where they were analysed using mass spectrophotometry. Stable isotope data are expressed in $\delta$ notation (\%०) as the relative difference between ratios of samples and international standards (Vienna PeeDee Belemnite and air for carbon and nitrogen, respectively).

\section{Sample processing for fatty acid profiles}

All samples for fatty acid analyses were stored at $-80^{\circ} \mathrm{C}$ under $\mathrm{N}_{2}$ until extraction following a method adapted from Torre-Ruiz et al. (2007) and originally modified from Parrish (1999). Samples were extracted in 2 washes of chloroform:methanol $(2: 1 \mathrm{v} / \mathrm{v})$, sonicated on ice, and the chloroform phase was separated for methylation into fatty acid methyl esters with $\mathrm{BF}_{3}(10-14 \% \mathrm{w} / \mathrm{v}$ in methanol) at $80^{\circ} \mathrm{C}$. Fatty acid methyl esters were suspended in hexane and measured on an Agilent 6890 gas chromatograph with an Agilent 5973-N mass selective detector that was fitted with a CP Sil 88 for FAME fused-silica capillary column $(100 \mathrm{~m} \times 250 \mu \mathrm{m} \times 39 \mu \mathrm{m})$ set in splitless mode. Carrier gas $(\mathrm{He})$ flow rate was constant at $0.2 \mathrm{~mL} \mathrm{~min}^{-1}$. Inlet temperature was $300^{\circ} \mathrm{C}$, with initial temperature $70^{\circ} \mathrm{C}$ with an increase of $720^{\circ} \mathrm{C} \mathrm{min}^{-1}$, and detector temperature was set at $280^{\circ} \mathrm{C}$. The temperature program started at $80^{\circ} \mathrm{C}$ for $1 \mathrm{~min}$, increased at a rate of $4^{\circ} \mathrm{C} \mathrm{min}-1$ until reaching a temperature of $220^{\circ} \mathrm{C}$. This was maintained for $4 \mathrm{~min}$, heated at $4^{\circ} \mathrm{C} \min ^{-1}$ until $240^{\circ} \mathrm{C}$, where it was maintained for a final $15 \mathrm{~min}$. The total temperature program lasted for 60 minutes. Fatty acid methyl esters were identified by retention times and mass spectra in full scan mode previously calibrated with standards: 37-Component FAME Mix (47885-4), PUFA No1; Marine Source (47033) and PUFA No3; Menhaden Oil (47085-4; all Supelco, Germany).

\section{Data analysis}

\section{Community composition of the macroinvertebrate assemblages colonising the three substrata} (NW, WS and WW) was compared by non-metric multidimensional scaling (nMDS) and analysis of similarities (ANOSIM) using the package vegan in R (Oksanen et al., 2013). These analyses were run on $\log (x+1)$-transformed macroinvertebrate data with Bray-Curtis distance among samples. We also computed Shannon-Wiener diversity indices and the rarefied taxonomic richness using the functions also implemented in the $R$ package vegan. The values of those metrics and the total 
abundances were compared among the three groups of samples (NW, WS and WW) through analysis of variances (ANOVA).

We estimated the relative importance of the trophic sources to the diet of the studied macroinvertebrate taxa using mixing models implemented in the SIAR package in R (Parnell et al., 2008; Parnell et al., 2010). Such models are based on a Bayesian approach and estimate the probability distributions to a consumer diet starting from the $\delta^{13} \mathrm{C}$ and $\delta^{15} \mathrm{~N}$ signature of each consumer, that of each source (mean \pm standard deviation) and the trophic enrichment factor (TEF). We used the TEF values reported by Post (2002), i.e. $0.4 \pm 1.3 \%$ for $\delta^{13} \mathrm{C}$ and $3.4 \pm 1.0 \%$ for $\delta^{15} \mathrm{~N}$. For predator taxa, we doubled the TEF values. Since Hydropsyche sp. can show both primary consumer and predatory behaviour, we included in the model both TEF and doubled TEF values, and the results were combined a-posteriori. We ran the models for each taxon including all trophic resources that were present at the site. If two sources are located in the same isotopic space, it may be impossible for the model to determine the differences in their contributions (Ward et al., 2011; Parnell et al., 2013). To account for that, the models were checked for correlations among resources (by using the function "siarmatrixplot" of the R package SIAR) and the resources that showed strong $(>60)$ negative correlations in at least one model were a-posteriori combined (Ward et al., 2011; Parnell et al., 2013). Thus seston inferred from the isotopic signature of unionid mussels was combined with filamentous algae because they were negatively correlated in several models, thus forming the group "unio-derived seston and filamentous algae". Epixylic periphyton and bryophytes were also combined because they were negatively correlated in several models (epixylic autochthonous material). Grass and leaves were considered separately in the SIAR models, but the results were then a-posteriori aggregated as a collective "terrestrial source" since we were interested in the relative contribution of the allochthonous riparian subsidies. Wood was considered separate from the "terrestrial source" group as it requires a specialized feeding behaviour.

We up-scaled the stable isotope results obtained for single taxa to the community level by weighting the diet composition of the single taxa (output of the SIA mixing models) by their mean 
biomass within the assemblage. The mean biomass of each taxon was computed from the average of individual dry weight of the samples that were dried for isotope analysis, multiplied by the mean abundance of that taxon.

We included all fatty acids in the analysis greater than $1 \%$ of all quantified fatty acids. The fatty acid profiles of both basal resources and consumers were ordinated using nMDS using percent composition of all quantified fatty acids. Differences among the overall profiles were compared using ANOSIM, and similarity percentage analysis (SIMPER) was used to determine the specific fatty acids responsible for the difference between profiles. Fatty acid profiles for wood and leaves, being Alnus sp., were grouped for the ordination. The nMDS, ANOSIM, and SIMPER were conducted in the $\mathrm{R}$ package vegan (Oksanen et al., 2013).

Fatty acids were subdivided into the four major fatty acid classifications: saturated fatty acids (SAFA), monounsaturated fatty acids (MUFA), $18 \mathrm{C}$ polyunsaturated fatty acids (PUFA), and $\geq 20 \mathrm{C}$ highly-unsaturated fatty acids (HUFA), in addition to bacterial fatty acids (BrFA), the sum of quantified bacterial fatty acids in this study (i.e. 15:0 and 17:0), as has been done in previous studies (Rajendran, Suwa \& Urushigawa, 1993; Alfaro et al., 2006). The ratio between the sum of all omega-3 and omega- 6 fatty acids was also calculated as an indicator of the influence of allochthonous or autochthonous matter in the diet (Torres-Ruiz, Wehr \& Perrone, 2007; Taipale, Kainz \& Brett, 2015). For basal resources, total fatty acid content was listed per unit dry weight of the basal resource, to indicate FA content ingested by consumers per unit weight of food, and as a percentage to examine indicative biomarkers. Consumer fatty acid content was also examined as a percentage of all fatty acids to determine diet biomarkers. Differences in fatty acid classes and trophic biomarkers were compared across basal resources and across mesohabitat locations for individual consumers, using ANOVA in the R package car (Fox et al., 2012). Post-hoc tests were examined with an F-test with holm $\mathrm{p}$-adjustment using the testlnteractions function in $\mathrm{R}$ package phia (Rosario-Martinez, 2013). Significance level was set for all tests at $\alpha<0.05$.

\section{Results}


216 A total of 32 taxa was collected from the three sampled substrata (Table 1), each of which was

217 colonised by a different macroinvertebrate assemblage (ANOSIM: $R=0.92, p=0.001$; Fig. 2).

218 Chironomidae was the dominant taxonomic group in all three datasets, representing on average $21972 \%$ of the abundance in both wood-poor (NW) and wood-rich sediments (WS), and $80 \%$ of the total abundance on the wood surface (WW). The second most abundant group was Caenis sp. in 221 the wood-poor and wood-rich sediments (16\% and $7 \%$ respectively of total abundance), and 222 Oligochaeta on the wood surface (14\% of total abundance). The highest total invertebrate abundances were recorded on the wood surface (mean $12.8 \pm 6.9 \times 10^{3}$ individuals $\mathrm{m}^{-2}$; mean \pm s.d.), followed by wood-rich sediments $\left(7.4 \pm 2.8 \times 10^{3}\right)$ and least in wood-poor sediments $(6.4 \pm 4.1$ $\mathrm{x} 10^{3}$ ), although this was not significantly different (ANOVA, $F=2.97, d f=2, p=0.08$ ). The highest rarefied taxa richness $(A N O V A, F=43.68, d f=2, p<0.01$ ) was recorded in sediments in the woodrich site $\left(25.5 \pm 4.0 \mathrm{~m}^{-2}\right)$, followed by the wood-poor site $(16.3 \pm 1.9)$ and then the LW surface $(11.0 \pm 1.7)$. The highest values of Shannon-Wiener diversity index (ANOVA, $F=12.36, d f=2$, $\mathrm{p}<0.01)$ were recorded on the sediment around $L W$ in the wood-rich site $\left(1.53 \pm 0.18 \mathrm{~m}^{-2}\right)$ followed by the wood-poor site $(1.17 \pm 0.18)$ and the LW surface $(1.11 \pm 0.06)$.

Stable isotopes: diet composition of the studied taxa

All consumers were extremely ${ }^{13} \mathrm{C}$-depleted, with average $\delta^{13} \mathrm{C}$ values of $-35.6 \pm 0.2 \%$, while most food resources had appreciably higher $\delta^{13} \mathrm{C}$ ranging from -31.5 to $-21.7 \%$ (Fig. 3). Periphyton on mussels had the highest $\delta^{13} \mathrm{C}$ of all food resources, ranging from -21.7 to $-27.9 \%$, while filamentous algae (-39.9 to $-38.5 \%$ ) and unio-derived seston (-37.0 to $-35.7 \%$ ) had the lowest $\delta^{13} \mathrm{C}$. The stable isotope mixing model indicated that unio-derived seston/filamentous algae were 237 the dominant basal resources for all taxa on the three substrata (ranging from $41 \%$ to $75 \%$ of 238 macroinvertebrate diets), with the exception of Oligochaeta that showed similar contributions to the 239 diet from periphyton/bryophytes (See Fig. S2). The contribution of periphyton/bryophytes to the diet of specific macroinvertebrate taxa ranged from $8 \%-49 \%$ and that of grass/leaves from $6 \%-26 \%$,

241 while the other food resources represented only minor fractions. The diets of specific 
macroinvertebrate taxa did not significantly differ across the three different substrata (as shown by the overlap of $95 \%$ credible intervals).

Stable isotopes: trophic bases of the macroinvertebrate assemblages

245 The assemblage level analyses indicated that, although unio-derived seston/filamentous algae were the most important resources in all three substrates, the contribution of the different trophic resources to macroinvertebrate biomass greatly differed among the three substrates (Fig. 4). The total biomass supported by unio-derived seston/filamentous algae increased with increasing proximity to wood $(\mathrm{NW}<\mathrm{WS}<\mathrm{WW})$.

250 Epixylic material (periphyton and bryophytes) increased in importance in the diet with increasing

251 proximity to wood, supporting a 1.4-fold increased macroinvertebrate biomass in wood-rich 252 sediment and a 4.3-fold increase on the wood-surface compared to NW. Those differences were 253 statistically significant as shown by the lack of overlap of $95 \%$ credible intervals (Fig. 4). Grass and 254 leaves also supported higher biomass on the LW surface $\left(13.75 \pm 1.62 \mathrm{mg} \mathrm{m}^{-2}\right)$ and on river-bed 255 sediments around the LW in the wood-rich site $\left(14.42 \pm 1.37 \mathrm{mg} \mathrm{m}^{-2}\right)$ than in the wood-poor site 256 (7.54 $\pm 0.54 \mathrm{mg} \mathrm{m}^{-2}$; Fig. 4), although such difference was not significant (overlap of credible 257 intervals).

The major fatty acid constituents, 14:0, 16:0, 18:0, 18:1w9c (oleic acid, OA), and 20:5w3 (eicosapentaenoic acid, EPA) accounted for $60 \%$ of the total fatty acids in the study. However, the proportion of these FAs, and other important FA biomarkers, varied considerably across the basal resources and taxa examined.

Fatty acid profiles of the basal resources were not significantly different between wood-rich and wood-poor reaches. Autochthonous sources, with the exception of filamentous algae, contained the most total fatty acids by weight (Table 2). Periphyton on mussels had the most fatty acids available for consumers (51.93 $\pm 4.97 \mathrm{mg} \mathrm{g}^{-1} \mathrm{dry}$ weight); in contrast, organic sediments had fatty acid concentrations nearly an order of magnitude smaller (5.68 $\pm 2.43 \mathrm{mg} \mathrm{g}^{-1}$; Table 2). Saturated 
fatty acids (SAFAs) were the most abundant fatty acid class across all basal resources (48 - 68\%), and highly unsaturated fatty acids (HUFAs) were the least abundant fatty acid class on average, although this was highly variable by source (periphyton on mussels: $19.1 \pm 0.9 \%$ - Grass: $4.6 \pm 0.6 \%$; Table 2).

A non-metric multidimensional scaling (nMDS) ordination of the fatty acid profile roughly separated the available basal resources into three groups: 1) periphyton on mussels, 2) periphyton on wood and bryophytes, and 3) filamentous algae, wood/leaves, grass, and sediment (Fig. 5).

Periphyton on mussels was characterized by the greatest $\omega 3: \omega 6$ ratio (3.5) and high levels of HUFA (19.1 $\pm 0.9 \%)$, particularly of eicosapentaenoic acid (EPA: $20: 5 \omega 3 ; 12.4 \pm 0.8 \%)$ and

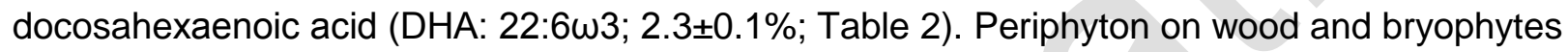
contained lower $\omega 3: \omega 6$ ratios $(2.5 \pm 0.3$ and $1.9 \pm 0.3)$ than periphyton on mussels, but these were still significantly greater than in allochthonous sources (Table 2), and periphyton on wood contained the second-highest levels of EPA quantified in the study (8.0 $\pm 0.8 \%)$ and bryophytes contained the highest levels of both arachidonic acid (ARA: $20: 4 \omega 6 ; 2.7 \pm 0.3 \%$ ) and DHA (2.5 $\pm 0.7 \%$; Table 2).

Terrestrial matter and sediments contained substantially less HUFA than autochthonous sources (Table 2). The ratio of omega-3:omega-6 fatty acids ( $\omega 3: \omega 6)$ was lowest in allochthonous sources, near or below 1, and sediment was slightly greater than 1 (Table 2). Filamentous algae, which were collected only in wood habitats, had a similar fatty acid profile to terrestrial material (grasses, wood, and leaves), although one sample contained a profile similar to periphyton on wood. Transported organic matter (TOM) was also highly variable between samples, with several samples similar to sediments and two with a greater autochthonous signal. TOM also exhibited the greatest levels of bacterial fatty acids seen in the study $(5.3 \pm 0.6 \%)$ and the $\omega 3: \omega 6$ ratio was $1.35 \pm 0.24$, indicating a composition predominately consisting of allochthonous sources.

Most macroinvertebrate taxa had fatty acid profiles similar to the range of available food resources, with most consumers having similar signatures to bryophytes/periphyton on wood and periphyton 
near periphyton on mussels. The net-spinning caddisfly Hydropsyche pellucidula was present in all three locations, while the trumpet-net caddisfly from the group Polycentropodidae was found exclusively in NW. H. pellucidula had substantially different fatty acid profiles in wood-rich and wood-poor locations, suggesting different diets. Both WS and WW samples grouped closely with periphyton on mussels, contained high levels of HUFA and $\omega-3$ fatty acids, and were significantly different from NW locations (Fig. 5; ANOSIM: $R=0.682, P=0.002$ ). Compared to NW, $H$. pellucidula in wood locations had increased 12:0, 2-fold greater EPA, 16:1, 18:3w3, and 2-fold

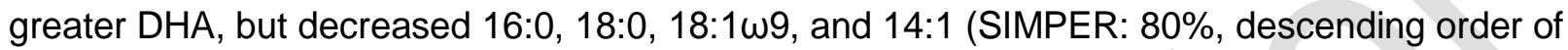
importance; Table S1). However, the $\omega 3: \omega 6$ of $H$. pellucidula in NW, even though lower than in both wood habitats, was still extremely high $(2.9 \pm 0.1)$, indicating a diet dominated by autochthonous sources (Table S1).

Diptera primarily comprised Chironomidae, which were significantly different among all three sampling locations, although this separation was not along any clear resource gradient (Fig. 5; ANOSIM: $R=0.589, P=0.006)$. WW Chironomidae were located centrally in the plot near periphyton on wood, while NW Chironomidae were located to the lower right, and WS

310 Chironomidae to the upper left, overlapping with the bryophyte signal. In comparison to NW, WW

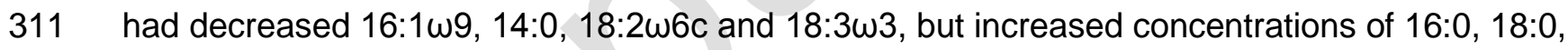
312 14:1, EPA, and 12:0 (SIMPER NW-WW: 82\%). WS Chironomidae in comparison to NW 313 Chironomidae contained decreased 16:1w9, 30\% less EPA content, 18:2w6c, 14:0, and 18:3w3, 314 but greater 16:0, 18:0, 5.5-fold greater DHA, ARA and 17:0 (SIMPER NW-WS: 79\%).

315 Chironomidae profiles in the two wood locations (WS and WW) also differed from one another, with

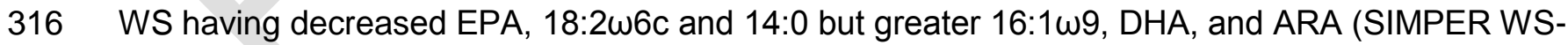
317 WW: 57\%).

318 A small number of taxa, primarily from the NW location, were located near the cluster of sediment 319 and allochthonous resource profiles. The Plecoptera, Nemouridae, a shredder/gatherer stonefly 320 found only in NW, had a profile highly similar to sediment (Fig. 5). While Ephemeroptera were 321 found in all three mesohabitat locations, in WW Baetis diets were similar to sediment and TOM, and in NW Caenis and Ephemera danica had a profile similar to wood and leaves. The predatory 
Coleopetera in NW, Orectochilus villosus, had a similar profile with the basal resources of sediment and wood and leaves, and probably fed on the nearby Plecoptera and Ephemeroptera in NW. The Heteroptera in NW, Aphelocheirus aestivalis larvae, while having a slightly different profile than most terrestrial sources, was most likely feeding on the Ephemeroptera present in NW. Ephemera found in WS was located away from other resources, in a cluster to the bottom right of the ordination. Several other taxa were located in this area, including NW Diptera (Chironomidae), and the predatory Heteroptera $A$. aestivalis in WS and the Odonata in both WS and NW locations which were probably feeding on these consumers in their respective locations.

Unionoida (Unio and Anodonta) and Dreissena polymorpha contained high levels of long-chain and branched fatty acids (e.g. 24:0, 22:2) and ARA, and with the exception of $D$. polymorpha in WS, grouped separately from all measured food resources. Despite feeding on seston, Unionoida and D. polymorpha profiles did not accurately represent the range of basal resources, as they are known to retain and possibly elongate commonly present fatty acids into long-chain branched forms which are not present or rare in seston (Gladyshev et al., 2011) and preferentially retain ARA (Newton et al., 2013). However, these two mussel taxa had substantially different $\omega 3: \omega 6$ ratios, with $D$. polymorpha containing high $\omega 3: \omega 6(2.1 \pm 0.5)$ and Unio with low $\omega 3: \omega 6(0.7 \pm 0.1$; Table $S 1)$.

The leech Glossiphonia sp., which was collected in only one sample, had a distinct fatty acid profile with extremely high levels of ARA ( $26 \%$ of total FA; Table S1), most likely due to its particular

341 feeding mechanism of sucking body fluids, and was very different from all food resources (outside 342 plot viewing area).

\section{Discussion}

344 The objectives of this study were to provide a methodological comparison of stable isotope and 345 fatty acid food web methods, and to determine how the presence of large wood altered the trophic 346 base of the macroinvertebrate consumer assemblage. Overall, the combination of stable isotope 347 analysis with fatty acid biomarkers provided complementary data about how wood caused changes to the trophic base of the macroinvertebrate assemblage, and was particularly useful in addressing 
349 the complex mix of lacustrine and riverine basal resources of both autochthonous and 350 allochthonous origins.

351 Stable isotope data suggested that the biomass of the consumer assemblage in the studied reach 352 of the Płociczna River was largely supported by the combined "seston and filamentous algae" 353 resource across all wood-rich and wood-poor habitat locations. Fatty acid profiles, however, 354 suggested filamentous algae were not a substantial part of the trophic base. Filamentous algae were only found in the wood-rich reach and were relatively rare, being restricted to a few small patches in over $300 \mathrm{~m}$ of channel. Therefore, even though seston and filamentous algae were combined isotopically within the stable isotope mixing model, this suggests that the dominant basal support was seston, which is likely to have originated from Lake Sitno located $700-1000 \mathrm{~m}$ upstream of the sampling locations. The presence of wood clearly decreased the reliance of the macroinvertebrate assemblage on seston, as the trophic base shifted to use more epixylic autochthonous production by periphyton and bryophytes. Despite wood creating accumulations of detritus and organic matter in nearby sediments, stable isotopes suggest that this was relatively unimportant to the overall trophic base of the macroinvertebrate assemblage.

The results of the fatty acid biomarker profiles, in contrast, did not explicitly show a dominant seston signature supporting the macroinvertebrate assemblage. Instead, fatty acid profiles effectively discriminated between an autochthonous and allochthonous trophic base, primarily through HUFA content and $\omega 3: \omega 6$ ratios, and indicated that most consumer diets were supported by high-quality autochthonous production, such as bryophytes and periphyton. In addition to most consumer profiles being similar to these sources, most consumers maintained a $\omega 3: \omega 6$ ratio greater than 1, an indicator of a diet dominated by autochthonous matter (Torres-Ruiz, Wehr \& 371 Perrone, 2007; Taipale, Kainz \& Brett, 2015). Few consumers had profiles similar to terrestrial matter and sediment detritus, further reinforcing conclusions from the stable isotope data that allochthonous matter was a relatively unimportant part of the diet.

374 Fatty acid profiles suggesting a largely autochthonous trophic base do not explicitly contradict stable isotope data that suggest seston was a dominant part of the diet of many consumers. 
376 Seston is a mix of allochthonous and autochthonous sources, and includes phytoplankton,

377 bacteria, and processed terrestrial matter that may be present in various size fractions, and while

378 fatty acid profiles may lack the resolution to distinguish between riverine or lacustrine origins (e.g. a

379 "diatom signature" is similar whether from periphyton or phytoplankton sources: Dethier et al.,

380 2013; Taipale et al., 2013), they can effectively descriminate between the origin of food resources

381 (i.e. allochthonous or autochthonous). As a result, consumers that had stable isotope signatures

382 indicating a predominantly seston diet and either an allochthonous or autochthonous fatty acid

383 profile suggests selective feeding on particular fractions of the seston, a feeding behaviour noted in

384 other studies (Thorp \& Delong, 2002; Delong \& Thorp, 2006). This is likely to be the case for the

385 net-spinning caddisfly Hydropsyche pellucidula, which was estimated to have a similar diet

386 dominated by seston ( $>75 \%$ ) across all three habitat locations by stable isotope analysis, but fatty

387 acid profiles detected diet differences between wood-rich and wood-poor habitats. Specifically,

388 individuals collected from wood-rich substrata had greater $\omega 3: \omega 6$ ratios and higher tissue

389 concentrations of HUFA and EPA, indicative of increased autochthonous matter in a seston-

390 dominated diet. Wood provides an elevated position in the water column for Hydropsyche to attach

391 their nets, and this may provide access to a more nutritive fraction of the seston than at the river-

392 bed, as vertical stratification of transported particles has been suggested in low-slope, sand-bed

393 rivers (Wright \& Parker, 2004). This diet change may have implications for the success of

394 Hydropsyche populations, as increased HUFA, and especially EPA, have been associated with

395 increased Hydropsyche growth rates (Torres-Ruiz, Wehr \& Perrone, 2010), and possibly other

396 fitness measures such as survival and fecundity, as seen in other taxa (Müller-Navarra et al., 2000;

397 Kim, Arts \& Yan, 2014; Taipale et al., 2014).

398 Non-filter feeder taxa, such as Baetis sp. (mostly grazer and gatherer-collector), Caenis sp. (mostly 399 gatherer-collector), Chironomidae (mostly gatherer-collectors, but with genus- or species-specific 400 differences in feeding behaviours) and, to a lesser extent, Oligochaeta (mostly gatherer-collector), 401 also showed a strong sestonic isotopic signature. This signature was most likely due to feeding on 402 settling seston, which is enhanced in the low-flow areas around LW (Smock, Metzler \& Gladden, 403 1989; Ehrman \& Lamberti, 1992; Daniels, 2006; Cordova et al., 2008), and also by the benthic- 
pelagic coupling provided by filter feeder taxa (Wotton et al., 1998; Vaughn, Gido \& Spooner, 2004; Howard \& Cuffey, 2006). Fatty acid profiles also indicated a shift to a more autochthonous diet at wood-rich sites for Chironomidae and Ephemeroptera. While this may be due to an actual shift in the specific diets of these taxa (Chapman \& Demory, 1963; Rosi-Marshall \& Wallace, 2002), it may also be a result of compositional changes to the available food resources across the three substrata. For example, Chironomidae show large genus- or species-specific differences in feeding behaviours (Ehrman \& Lamberti, 1992), and thus the changes in diet that we recorded might be a result of sub-family shifts in taxonomic composition and their associated feeding preferences.

Consumers in this study had low $\delta^{13} \mathrm{C}$, more ${ }^{13} \mathrm{C}$-depleted than most available food resources, and thus the seston value derived from Unio mussels was needed to resolve the consumer stable isotope signals. The $\delta^{13} \mathrm{C}$ of Unio-derived seston was substantially lower than that of the $>125 \mu \mathrm{m}$ TOM fraction, and TOM was estimated to be a minimal part of the diet in the stable isotope mixing model. Such differences may be due to the high seasonal variability of the isotopic signature of lacustrine seston, with bulk isotopic values generally more ${ }^{13} \mathrm{C}$-depleted in winter and more enriched in spring (Zohary et al., 1994). Therefore, Unionid mussel tissues may have partially retained this previous isotopic signature (Atkinson et al., 2014; Cabana \& Rasmussen, 1996) that was no longer present in the $125 \mu \mathrm{m}$ TOM fraction at the time of sampling (April). Alternatively, the difference in the isotopic values may be due to a selective feeding behaviour of the unionid mussels on different fractions of the seston (e.g. ultra-fine nutritive particles, such as ${ }^{13} \mathrm{C}$-depleted bacteria) or to the pedal feeding behaviour of mussels (Nichols \& Garling, 2000). Previous studies have suggested that seston $<100 \mu \mathrm{m}$ in size is in fact more ${ }^{13} \mathrm{C}$-depleted than seston $>100 \mu \mathrm{m}$ (Delong \& Thorp, 2006), which further supports the idea of size-selective feeding by both unionid mussels and other consumers with similarly low stable isotope values. However, since other studies suggest that unionid mussels can feed on particles of a broad size range up to $250 \mu \mathrm{m}$ (Vaughn, Gido \& Spooner, 2004), further investigation is required. 
Differences in the fatty acid profiles between Unionid and Dreissena mussels, particularly in the $\omega 3: \omega 6$ ratio, may suggest taxa-specific feeding ecologies on different fractions of the seston.

However, fatty acids may be ineffective at directly determining mussel diets due to the noted ability for mussels to preferentially retain or modify fatty acids into forms which are not present or rare in the seston (Gladyshev et al., 2011), including ARA (Newton et al., 2013). While Dreissena fatty acid profiles have been shown to reflect changes in catchment land-use (Larson et al., 2013) and habitats in large rivers (Larson et al., 2015), without further research into the process of fatty acid trophic modification by mussels, fatty acid profiles may be less applicable for directly determining the specific composition of mussel diets than for other consumers.

The strong influence of lacustrine seston from Lake Sitno on the trophic base of benthic macroinvertebrates in the Płociczna river effectively subsidised an increase in biomass in downstream assemblages (Richardson \& Mackay, 1991; Hillbricht-Ilkowska, 1999) and created a strong coupling between lake and river productivity (Perry \& Sheldon, 1986; Junger \& Planas, 1994). The lower $\delta^{13} \mathrm{C}$ of seston and high levels of bacterial fatty acids in the food web suggests that this lacustrine carbon is likely produced via a microbial link, i.e. bacteria-flagellate-ciliateDaphnia; (Kankaala et al., 2006). This lake-derived carbon then enters the river ecosystem and provides a cross-ecosystem food subsidy for benthic consumers that may be otherwise limited by low local primary productivity (Perry \& Sheldon, 1986; Junger \& Planas, 1994). River-lake coupling is expected to be particularly strong in lowland sand-bed rivers and in other lowland rivers with fine, unstable sediments, as sediment instability limits in-stream primary production to support overall ecosystem productivity (Atkinson et al., 2008).

However, a recent study has shown that production based on a predominantly bacterial carbon source is highly limited by the availability of physiologically essential lipids and fatty acids derived from algal production, without which bacteria cannot support zooplankton productivity (Taipale et al., 2014). Therefore, an increase in carbon subsidies from either bacterial or terrestrial sources without addressing a limiting availability of physiological essential fatty acids may result in little change to secondary production. Indeed, large wood created accumulations of organic matter and 
allochthonous resources (i.e. leaves) which were otherwise minimal and limited to marginal areas of the channel, yet this oft-noted ability for wood to accumulate organic matter (Smock, Metzler \& Gladden, 1989) had little effect on the trophic base of the macroinvertebrate assemblage, most likely due to its low-nutritional quality. In contrast, large wood dramatically increased the amount of stable substratum for colonisation by periphyton and bryophytes (Golladay \& Sinsabaugh, 1991; Hax \& Golladay, 1993; Wondzell \& Bisson, 2003), and thus acted as a hotspot of otherwise limited high-nutritional quality autochthonous production. In addition, large wood also served as an attachment site for the net-spinning caddisfly Hydropsyche to feed on a more nutritive and autochthonous component of the seston. Overall, wood increased the contributions of high-quality autochthonous primary production to the trophic base of the macroinvertebrate assemblage.

These results are in contrast to a recent study using gut-content analysis which suggested that the trophic base around wood was mainly supported by transported amorphous detritus, presumably of allochthonous origin (Benke \& Bruce Wallace, 2015). While we also found that transported material provided a large contribution to the diet, our fatty acid data suggest that the seston and drifting detritus consumed were primarily of autochthonous, and not allochthonous, origin. Overall, the combined stable isotope and fatty acid approach contained in this study supports previous work emphasising the importance of high quality autochthonous resources for riverine productivity (Thorp \& Delong, 2002), even in light-limited rivers that contain high terrestrial inputs (Torres-Ruiz, Wehr \& Perrone, 2007; Lau, Leung \& Dudgeon, 2008; Lau, Leung \& Dudgeon, 2009).

In conclusion, our study showed that SIA and FA analyses complement each other and thus their combined use can improve studies of freshwater food webs, particularly where resources may be a complex mix of lacustrine and riverine origins. Since stable isotopes are subjected to seasonal and local variation, SIA can identify the contribution of food resources of different spatial origin (i.e. riparian zone, lake and river), but may be difficult to interpret due to seasonal changes and be unable to separate resources with similar isotopic signatures. On the other hand, fatty acids can be used to accurately estimate taxonomic groupings even with seasonal variations (Dethier et al., 2013; Taipale et al., 2013), although they do not distinguish between lacustrine or riverine origins. 
The results presented in this paper demonstrate that the presence of large wood decreases the strength of river-lake coupling by providing alternative basal resources, primarily through its role as a hard substratum supporting colonisation by periphyton/bryophytes and hence increasing local, high-quality autochthonous productivity. As the influence of lake subsidies decreases at increasing distance from the lake (Richardson \& Mackay, 1991; Hillbricht-Ilkowska, 1999), the role of large wood is likely to increase, as secondary production would be entirely dependent on the remainder of locally-produced food resources. Thus, river management that would affect the availability of wood and its effects on habitat heterogeneity would ultimately alter patterns of energy flow and ecosystem productivity by changing the availability and nutritional-quality of basal food resources.

\section{Acknowledgments}

We thank Jürgen Schreiber for assistance in the field, Angela Kruger and Katrin Premke for assistance in the laboratory, Angela Gurnell for support with travel and logistics, and Mario Brauns for help with the stable isotope mixing models. This research was carried out within the Erasmus Mundus Doctorate Program SMART (http://www.riverscience.eu) funded by the Education, Audiovisual and Culture Executive Agency (EACEA) of the European commission.

\section{References}

Alfaro A.C., Thomas F., Sergent L. \& Duxbury M. (2006) Identification of trophic interactions within an estuarine food web (northern New Zealand) using fatty acid biomarkers and stable isotopes. Estuarine, Coastal and Shelf Science, 70, 271-286.

Allan E.L., Ambrose S.T., Richoux N.B. \& Froneman P.W. (2010) Determining spatial changes in the diet of nearshore suspension-feeders along the South African coastline: stable isotope and fatty acid signatures. Estuarine, Coastal and Shelf Science, 87, 463-471.

Anderson N.H. (1989) Xylophagous chironomidae from Oregon streams. Aquatic Insects, 11, 3345.

Anderson N.H., Sedell J.R., Roberts L.M. \& Triska F.J. (1978) The role of aquatic invertebrates in processing of wood debris in coniferous forest streams. American Midland Naturalist, 100, 64-82. 
Anderson N.H., Steedman R.J. \& Dudley T. (1984) Patterns of exploitation by stream invertebrates of woody debris (xylophagy). Verhandlungen. Internationale Vereinigung fur theoretische und angewandte Limnologie, 22, 1847-1852.

Atkinson B.L., Grace M.R., Hart B.T. \& Vanderkruk K.E.N. (2008) Sediment instability affects the rate and location of primary production and respiration in a sand-bed stream. Journal of the North American Benthological Society, 27, 581-592.

Atkinson C.L., Christian A.D., Spooner D.E. \& Vaughn C.C. (2014) Long-lived organisms provide an integrative footprint of agricultural land use. Ecological Applications, 24, 375-384.

Benke A. \& Wallace J.B. (2003) Influence of wood on invertebrate communities in streams and rivers. In: The ecology and management of wood in world rivers. (Eds S.V. Gregory \& K.L. Boyer \& A.M. Gurnell), pp. 149-177. American Fisheries Society, Symposium 37, Bethesda, Maryland.

Benke A.C. \& Bruce Wallace J. (2015) High secondary production in a Coastal Plain river is dominated by snag invertebrates and fuelled mainly by amorphous detritus. Freshwater Biology, 60, 236-255.

Bilby R.E. (1981) Role of organic debris dams in regulating the export of dissolved and particulate matter from a forested watershed. Ecology, 62, 1234-1243.

Bilby R.E. \& Likens G.E. (1980) Importance of organic debris dams in the structure and function of stream ecosystems. Ecology, 61, 1107-1113.

Brett M. \& Müller-Navarra D. (1997) The role of highly unsaturated fatty acids in aquatic foodweb processes. Freshwater Biology, 38, 483-499.

Cabana G. \& Rasmussen J.B. (1996) Comparison of aquatic food chains using nitrogen isotopes. Proceedings of the National Academy of Sciences, 93, 10844-10847.

Chapman D.W. \& Demory R.L. (1963) Seasonal changes in the food ingested by aquatic insect larvae and nymphs in two Oregon streams. Ecology, 44, 140-146.

Cordova J.M., Rosi-Marshall E.J., Tank J.L. \& Lamberti G.A. (2008) Coarse particulate organic matter transport in low-gradient streams of the Upper Peninsula of Michigan. Journal of the North American Benthological Society, 27, 760-771. 
Daniels M.D. (2006) Distribution and dynamics of large woody debris and organic matter in a lowenergy meandering stream. Geomorphology, 77, 286-298.

Delong M.D. \& Thorp J.H. (2006) Significance of instream autotrophs in trophic dynamics of the Upper Mississippi River. Oecologia, 147, 76-85.

Dethier M.N., Sosik E., Galloway A.W., Duggins D.O. \& Simenstad C.A. (2013) Addressing assumptions: variation in stable isotopes and fatty acids of marine macrophytes can confound conclusions of food web studies. Mar. Ecol. Prog. Ser, 478, 1-14.

Ehrman T.P. \& Lamberti G.A. (1992) Hydraulic and particulate matter retention in a 3rd-order Indiana stream. Journal of the North American Benthological Society, 11, 341-349.

El-Sabaawi R., Dower J.F., Kainz M. \& Mazumder A. (2009) Interannual variability in fatty acid composition of the copepod Neocalanus plumchrus in the Strait of Georgia, British Columbia. Marine Ecology Progress Series, 382, 151-161.

Fox J., Weisberg S., Bates D. \& Fox M.J. (2012) Package 'car'. R Foundation for Statistical Computing, Vienna, Austria.

Fry T.J. \& Fuller R.L. (1991) The influence of temperature and food quality on the growth of Hydropsyche betteni (Trichoptera) and Simulium vittatum (Diptera). Journal of Freshwater Ecology, 6, 75.

Galloway A.W., Britton-Simmons K.H., Duggins D.O., Gabrielson P.W. \& Brett M.T. (2012) Fatty Acid Signatures Differentiate Marine Macrophytes At Ordinal and Family Ranks1. Journal of Phycology, 48, 956-965.

Gippel C.J., O'neill I.C., Finlayson B.L., Schnatz I. \& Saltveit S.J. (1996) Hydraulic guidelines for the re-introduction and management of large woody debris in lowland rivers. Regulated Rivers: Research \& Management, 12, 223-236.

Gladyshev M., Arts M. \& Sushchik N.I. (2009) Preliminary estimates of the export of omega-3 highly unsaturated fatty acids (EPA+ DHA) from aquatic to terrestrial ecosystems. In: Lipids in aquatic ecosystems pp. 179-210. Springer.

Gladyshev M.I., Sushchik N.N., Anishchenko O.V., Makhutova O.N., Kolmakov V.I., Kalachova G.S., Kolmakova A.A. \& Dubovskaya O.P. (2011) Efficiency of transfer of essential 
polyunsaturated fatty acids versus organic carbon from producers to consumers in a eutrophic reservoir. Oecologia, 165, 521-531.

Golladay S.W. \& Sinsabaugh R.L. (1991) Biofilm Development on Leaf and Wood Surfaces in a Boreal River. Freshwater Biology, 25, 437-450.

Gregory K.J., Gurnell A.M. \& Petts G.E. (1995) The role of dead wood in aquatic ecosystems in forests. In: Forests and Water. (Ed I.R. Brown), pp. 158-192. Institute of Chartered

Gurnell A.M. \& Linstead C. (1998) Interactions between large woody debris, hydrological processes and channel morphology in British headwater rivers. In: Hydrology in a Changing World, Proceedings of the British Hydrological Society International Conference, Exter July 1998. (Eds H. Wheater \& C. Kirby). John Wiley and Sons, Chichester, UK.

Gurnell A.M., Petts G.E., Harris N., Ward J.V., Tockner K., Edwards P.J. \& Kollmann J. (2000) Large wood retention in river channels: the case of the Fiume Tagliamento, Italy. Earth Surface Processes and Landforms, 255-275.

Gurnell A.M., Piegay H., Swanson F.J. \& Gregory S.V. (2002) Large wood and fluvial processes. Freshwater Biology, 47, 601-619.

Hax C.L. \& Golladay S.W. (1993) Macroinvertebrate colonization and biofilm development on leaves and wood in a boreal river. Freshwater Biology, 29, 79-87.

Hillbricht-Ilkowska A. (1999) Shallow lakes in lowland river systems: Role in transport and transformations of nutrients and in biological diversity. Hydrobiologia, 408, 349-358.

Hoffman A. \& Hering D. (2000) Wood-associated macroinvertebrates fauna in central-european streams. International Review of Hydrobiology, 85, 25-48.

Hoffmann A. \& Hering D. (2000) Wood-Associated Macroinvertebrate Fauna in Central European Streams. International Review of Hydrobiology, 85, 25-48.

Howard J.K. \& Cuffey K.M. (2006) The functional role of native freshwater mussels in the fluvial benthic environment. Freshwater Biology, 51, 460-474. 
Junger M. \& Planas D. (1994) Quantitative use of stable carbon isotope analysis to determine the trophic base of invertebrate communities in a boreal forest lotic system. Canadian Journal of Fisheries and Aquatic Sciences, 51, 52-61.

Kankaala P., Taipale S., Grey J., Sonninen E., Arvola L. \& Jones R.I. (2006) Experimental d13C evidence for a contribution of methane to pelagic food webs in lakes. Limnol. Oceanogr, 51, 2821-2827.

Kim N., Arts M.T. \& Yan N.D. (2014) Eicosapentaenoic acid limitation decreases weight and fecundity of the invading predator Bythotrephes longimanus. Journal of Plankton Research, $36,567-577$.

Larson J.H., Bartsch M.R., Gutreuter S., Knights B.C., Bartsch L.A., Richardson W.B., Vallazza J.M. \& Arts M.T. (2015) Differences between main-channel and off-channel food webs in the upper Mississippi River revealed by fatty acid profiles of consumers. Inland Waters, 5, 101-106.

Larson J.H., Richardson W.B., Knights B.C., Bartsch L.A., Bartsch M.R., Nelson J.C., Veldboom J.A. \& Vallazza J.M. (2013) Fatty acid composition at the base of aquatic food webs is influenced by habitat type and watershed land use. PloS one, 8.

Lau D.C.P., Leung K.M.Y. \& Dudgeon D. (2008) Experimental dietary manipulations for determining the relative importance of allochthonous and autochthonous food resources in tropical streams. Freshwater Biology, 53, 139-147.

Lau D.C.P., Leung K.M.Y. \& Dudgeon D. (2009) What does stable isotope analysis reveal about trophic relationships and the relative importance of allochthonous and autochthonous resources in tropical streams? A synthetic study from Hong Kong. Freshwater Biology, 54, $127-141$

Montgomery D.R., Buffington J.M., Smith R.D., Schmidt K.M. \& Pess G. (1995) Pool spacing in forest channels. Water Resources Research, 31, 1097-1105.

Moore J.W. \& Semmens B.X. (2008) Incorporating uncertainty and prior information into stable isotope mixing models. Ecology Letters, 11, 470-480. 
Müller-Navarra D.C., Brett M.T., Liston A.M. \& Goldman C.R. (2000) A highly unsaturated fatty acid predicts carbon transfer between primary producers and consumers. Nature, 403, 74-77. Newton T.J., Vaughn C.C., Spooner D.E., Nichols S.J. \& Arts M.T. (2013) Profiles of biochemical tracers in unionid mussels across a broad geographical range. Journal of Shellfish Research, 32, 497-507.

Nichols S. \& Garling D. (2000) Food-web dynamics and trophic-level interactions in a multispecies community of freshwater unionids. Canadian Journal of Zoology, 78, 871-882.

Oksanen J., Guillaume Blanchet F., Kindt R., Legendre P., Minchin P.R., O'hara R.B., Simpson G.L., Solymos P., Henry M., Stevens H. \& Wagner H. (2013) Vegan: Community Ecology Package. R package version 2.0-10. http://CRAN.R-project.org/package=vegan

Parnell A., Inger R., Bearhop S. \& Jackson A. (2008) SIAR: stable isotope analysis in R. $R$ package version, 3.

Parnell A.C., Inger R., Bearhop S. \& Jackson A.L. (2010) Source partitioning using stable isotopes: coping with too much variation. PLOS one, 5, e9672.

Parnell A.C., Phillips D.L., Bearhop S., Semmens B.X., Ward E.J., Moore J.W., Jackson A.L., Grey J., Kelly D.J. \& Inger R. (2013) Bayesian stable isotope mixing models. Environmetrics, 24, 387-399.

Parrish C.C. (1999) Determination of Total Lipid, Lipid Classes, and Fatty Acids in Aquatic Samples. In: Lipids in Freshwater Ecosystems. (Eds M.T. Arts \& B.C. Wainman), pp. 4-20. Springer New York.

Perhar G., Arhonditsis G.B. \& Brett M.T. (2013) Modelling the role of highly unsaturated fatty acids in planktonic food web processes: Sensitivity analysis and examination of contemporary hypotheses. Ecological Informatics, 13, 77-98.

Perry S.A. \& Sheldon A.L. (1986) Effects of exported seston on aquatic insect faunal similarity and species richness in lake outlet streams in Montana, USA. Hydrobiologia, 137, 65-77.

Pilotto F., Bertoncin A., Harvey G.L., Wharton G. \& Pusch M.T. (2014) Diversification of stream invertebrate communities by large wood. Freshwater Biology, 59, 2571-2583. 
Post D.M. (2002) Using stable isotopes to estimate trophic position: models, methods, and assumptions. Ecology, 83, 703-718.

Rajendran N., Suwa Y. \& Urushigawa Y. (1993) Distribution of phospholipid ester-linked fatty acid biomarkers for bacteria in the sediment of Ise Bay, Japan. Marine Chemistry, 42, 39-56.

Reeves G.H., Burnett K.M. \& Mcgarry E.V. (2003) Sources of large wood in the main stem of a fourth-order watershed in coastal Oregon. Canadian Journal of Forest Research, 33, 13631370.

Richardson J.S. \& Mackay R.J. (1991) Lake outlets and the distribution of filter feeders: an assessment of hypotheses. Oikos, 370-380.

Rosario-Martinez H. (2013) phia: post-hoc interaction analysis. R package version 0.1-3.

Rosi-Marshall E.J. \& Wallace J.B. (2002) Invertebrate food webs along a stream resource gradient. Freshwater Biology, 47, 129-141.

Sabater S., Gregory S.V. \& Sedell J.R. (1998) Community dynamics and metabolism of benthic algae colonizing wood rock substrata in a forest stream. Journal of Phycology, 34, 561-567.

Schröder M., Kiesel J., Schattmann A., Jähnig S.C., Lorenz A.W., Kramm S., Keizer-Vlek H., Rolauffs P., Graf W. \& Leitner P. (2013) Substratum associations of benthic invertebrates in lowland and mountain streams. Ecological Indicators, 30, 178-189.

Smock L.A., Metzler G.M. \& Gladden J.E. (1989) Role of debris dams in the structure and functioning of low-gradient headwater streams. Ecology, 70, 764-775.

Taipale S., Strandberg U., Peltomaa E., Galloway A.W.E., Ojala A. \& Brett M.T. (2013) Fatty acid composition as biomarkers of freshwater microalgae: analysis of 37 strains of microalgae in 22 genera and in seven classes. Aquatic Microbial Ecology, 71, 165-178.

Taipale S.J., Brett M.T., Hahn M.W., Martin-Creuzburg D., Yeung S., Hiltunen M., Strandberg U. \& Kankaala P. (2014) Differing Daphnia magna assimilation efficiencies for terrestrial, bacterial, and algal carbon and fatty acids. Ecology, 95, 563-576.

Taipale S.J., Kainz M.J. \& Brett M.T. (2015) A low w-3: $\omega-6$ ratio in Daphnia indicates terrestrial resource utilization and poor nutritional condition. Journal of Plankton Research, 37, 596610. 
Thorp J.H. \& Delong M.D. (2002) Dominance of autochthonous autotrophic carbon in food webs of heterotrophic rivers. Oikos, 96, 543-550.

Torres-Ruiz M., Wehr J.D. \& Perrone A.A. (2007) Trophic relations in a stream food web: importance of fatty acids for macroinvertebrate consumers. Journal of the North American Benthological Society, 26, 509-522.

Torres-Ruiz M., Wehr J.D. \& Perrone A.A. (2010) Are net-spinning caddisflies what they eat? An investigation using controlled diets and fatty acids. Journal of the North American Benthological Society, 29, 803-813.

Vannote R.L., Minshall G.W., Cummins K.W., Sedell J.R. \& Cushing C.E. (1980) The river continuum concept. Canadian Journal of Fisheries and Aquatic Sciences, 37, 130-137.

Vaughn C.C., Gido K.B. \& Spooner D.E. (2004) Ecosystem processes performed by unionid mussels in stream mesocosms: species roles and effects of abundance. Hydrobiologia, $527,35-47$.

Ward E.J., Semmens B.X., Phillips D.L., Moore J.W. \& Bouwes N. (2011) A quantitative approach to combine sources in stable isotope mixing models. Ecosphere, 2, art19.

Ward G.M. \& Aumen N.G. (1986) Woody debris as a source of fine particulate organic matter in coniferous forest stream ecosystems. Canadian Journal of Fisheries and Aquatic Sciences, 43, 1635-1642.

Wondzell S.M. \& Bisson P.A. (2003) Influence of wood on aquatic biodiversity. In: The Ecology and Management of Wood in World Rlvers. (Eds S.V. Gregory \& K.L. Boyer \& A.M. Gurnell), pp. 249-264. American Fisheries Society Symposium, Bethesda, MD.

Wotton R.S., Malmqvist B., Muotka T. \& Larsson K. (1998) Fecal pellets from a dense aggregation of suspension-feeders in a stream: An example of ecosystem engineering. Limnology and Oceanography, 43, 719-725.

Wright S. \& Parker G. (2004) Density stratification effects in sand-bed rivers. Journal of Hydraulic Engineering, 130, 783-795. 
701 Zohary T., Erez J., Gophen M., Berman-Frank I. \& Stiller M. (1994) Seasonality of stable carbon isotopes within the pelagic food web of Lake Kinneret. Limnology and Oceanography, 39, 1030-1043.

704 
706 Table 1: Taxa collected in the three mesohabitat locations in the Płociczna River, along with the 707 dominant functional feeding group and the assimilation analysis test conducted. NW= river-bed 708 sediments in the wood-poor site; WS= river-bed sediments in the wood-rich site; WW= the wood 709 surface in the wood-rich site. Shr=shredders; Grz=grazers; Prd=predator; Gat=gatherers;

710 AFF=active filterers; PFF=passive filterers; Min=miners.

\begin{tabular}{|c|c|c|c|c|c|c|}
\hline Taxon & Functional Group & $\begin{array}{l}\text { Analysed } \\
\text { for SIA }\end{array}$ & $\begin{array}{l}\text { Analysed } \\
\text { for FA }\end{array}$ & NW & WS & WW \\
\hline Anabolia sp. & Shr/Grz/Prd/Gat & $\mathrm{X}$ & & $\mathrm{X}$ & & \\
\hline Anodonta anatina & AFF & $X$ & $x$ & $x$ & & \\
\hline Aphelocheirus aestivalis adult & Pred & $x$ & $x$ & & $x$ & \\
\hline Aphelocheirus aestivalis larvae & Pred & $x$ & $x$ & $X$ & $x$ & $x$ \\
\hline Asellus aquaticus & Gat/Grz/Shr & $x$ & & $x$ & & \\
\hline Baetis sp. & Grz/Gat & $x$ & $x$ & & $x$ & $x$ \\
\hline Bithynia tentaculata & AFF/Grz/Gat & $x$ & $x$ & $x$ & $x$ & \\
\hline Caenis sp. & Gat & $x$ & $x$ & $x$ & $x$ & $x$ \\
\hline Calopteryx sp. & Prd & $x$ & 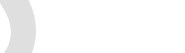 & $x$ & $x$ & \\
\hline Chironomidae & Gat/AFF/Grz/Min/Prd & $x$ & $x$ & $\mathrm{X}$ & $\mathrm{x}$ & $x$ \\
\hline Dreissena polymorpha & AFF & $x$ & $x$ & $x$ & $x$ & \\
\hline Ephemera danica & AFF/Gat & $x$ & $x$ & $x$ & $x$ & $x$ \\
\hline Gammarus pulex & Shr/Gat/Grz/Prd & & $x$ & & $x$ & \\
\hline Gammarus roselii & Shr/Gat/Grz/Prd & 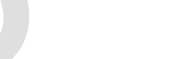 & $x$ & & $x$ & \\
\hline Glossiphonia sp. & Prd & $x$ & $x$ & $x$ & & \\
\hline Gomphus sp. & Prd & $x$ & $x$ & $x$ & $x$ & \\
\hline Hydropsyche pellucidula & PFF/Prd/Grz & $x$ & $x$ & $x$ & $\mathrm{x}$ & $x$ \\
\hline Limnephilidae & Shr/Grz/Prd/Gat & $x$ & & & $x$ & \\
\hline Nemouridae & Shr/Gat & $X$ & $x$ & $x$ & & \\
\hline Neureclipsis bimaculata & PFF/Prd & $x$ & & & $x$ & \\
\hline Oligochaeta & Gat & $x$ & & $x$ & $x$ & \\
\hline Ophigomphus cecilia & Prd & $x$ & $x$ & $x$ & & \\
\hline Orectochilus villosus & Prd & $x$ & $x$ & $x$ & $x$ & $x$ \\
\hline Platycnemis sp. & Prd & $x$ & $x$ & $x$ & & \\
\hline Polycentropodidae & Prd / PFF & $X$ & $x$ & $x$ & $X$ & $x$ \\
\hline Potamopyrgus antipodarum & Oth/Gat/Shr/Graz & $x$ & $x$ & $x$ & & \\
\hline Psychomia pusilla & Grz/Gat/PFF/Prd & $x$ & & & & $x$ \\
\hline Sphaeriidae & AFF & $x$ & $x$ & $x$ & $X$ & $x$ \\
\hline Tabanidae & Prd & $X$ & $x$ & $x$ & $\mathrm{X}$ & \\
\hline Theodoxus fluviatilis & Grz & $x$ & & $x$ & & \\
\hline Unio pictorum & AFF & $x$ & $x$ & $x$ & $x$ & \\
\hline Unio tumidus & AFF & $x$ & $x$ & $x$ & $x$ & \\
\hline
\end{tabular}


712 Table 2: Fatty acid composition data for the various food resources. Values indicate mean and standard error. Total fatty acid content is given by 713 weight $\left(\mathrm{mg} \mathrm{g}^{-1}\right)$ and indicates the sum of all quantified FA, and the subdivision into the 4 main fatty acid classes is indicated by percentage of all 714 quantified fatty acids. No significant differences were seen between wood-rich and wood-poor locations, and data is the average across locations SAFA $=$ saturated fatty acids. MUFA = monounsaturated fatty acids. PUFA = polyunsaturated fatty acids. HUFA = highly unsaturated fatty acids.

716 EPA = eicosapentaenoic acid; $20: 5 \omega 3, \mathrm{DHA}=$ docosahexaenoic acid; $22: 6 \omega 3$, and ARA = arachidonic acid; $20: 4 \omega 6$. BrFA = the sum of quantified 717 bacterial fatty acids $(15: 0,17: 0)$. $\omega 3: \omega 6=$ the ratio of the sum of all omega- 3 to omega- 6 fatty acids. Letters indicate post-hoc significant 718 differences at $\mathrm{P}<0.05$.

\begin{tabular}{|c|c|c|c|c|c|c|c|c|c|c|}
\hline \multirow[t]{2}{*}{ Basal Resources } & \multirow{2}{*}{$\begin{array}{l}\text { Total FA } \\
\text { Content } \\
\left(\mathrm{mg} \mathrm{g}^{-1}\right)\end{array}$} & \multicolumn{4}{|c|}{ Proportion of Fatty Acid Classes (\%) } & \multicolumn{4}{|c|}{ Specific Fatty Acid Biomarkers (\%) } & \multirow{2}{*}{$\begin{array}{c}\text { Biomarker } \\
\text { Ratio } \\
\omega 3: \omega 6\end{array}$} \\
\hline & & SAFA & MUFA & PUFA & HUFA & EPA & $\mathrm{DHA}$ & ARA & BrFA & \\
\hline Mussel periphyton & $51.93 \pm 4.97^{a}$ & $55.1 \pm 1.5^{\mathrm{a}}$ & $14.3 \pm 2.5^{d}$ & $11.5 \pm 0.7^{\mathrm{ab}}$ & $19.1 \pm 0.9^{a}$ & $12.4 \pm 0.8^{a}$ & $2.3 \pm 0.1^{\mathrm{ab}}$ & $1.7 \pm 0.1^{\mathrm{ab}}$ & $2.2 \pm 0.3^{b}$ & $3.5 \pm 0.1^{\mathrm{a}}$ \\
\hline Wood periphyton & $44.32 \pm 22.82^{\mathrm{ab}}$ & $60.7 \pm 1.0^{\mathrm{a}}$ & $17.9 \pm 0.6^{\mathrm{cd}}$ & $8.4 \pm 0.4^{\mathrm{abc}}$ & $13.1 \pm 0.6^{\mathrm{ab}}$ & $8.0 \pm 0.8^{\mathrm{ab}}$ & $1.6 \pm 0.4^{\mathrm{abc}}$ & $1.6 \pm 0.2^{\mathrm{ab}}$ & $4.4 \pm 0.9^{\mathrm{ab}}$ & $2.5 \pm 0.3^{\mathrm{ab}}$ \\
\hline Bryophyte & $40.87 \pm 8.76^{\mathrm{ab}}$ & $56.6 \pm 5.6^{a}$ & $18.3 \pm 2.9^{\mathrm{cd}}$ & $10.9 \pm 0.8^{\mathrm{abc}}$ & $14.3 \pm 1.5^{\mathrm{a}}$ & $7.6 \pm 1.3^{\mathrm{ab}}$ & $2.5 \pm 0.7^{a}$ & $2.7 \pm 0.3^{a}$ & $3.4 \pm 0.5^{\mathrm{ab}}$ & $1.9 \pm 0.3^{\mathrm{ab}}$ \\
\hline Grass & $16.82 \pm 3.24^{\mathrm{bc}}$ & $58.7 \pm 1.7^{a}$ & $22.4 \pm 1.9^{\mathrm{abc}}$ & $14.3 \pm 2.3^{\mathrm{a}}$ & $4.6 \pm 0.6^{c}$ & $2.5 \pm 0.4^{c}$ & $0.4 \pm 0.1^{\mathrm{cd}}$ & $0.9 \pm 0.1^{b}$ & $4.4 \pm 0.7^{\mathrm{ab}}$ & $0.8 \pm 0.1^{c}$ \\
\hline Wood \& leaves & $15.66 \pm 2.35^{c}$ & $59.3 \pm 1.5^{a}$ & $21.4 \pm 0.7^{b c}$ & $11.3 \pm 1.1^{a b c}$ & $8.0 \pm 1.1^{b c}$ & $4.6 \pm 0.8^{\mathrm{bc}}$ & $0.7 \pm 0.1^{\mathrm{bcd}}$ & $1.4 \pm 0.2^{\mathrm{b}}$ & $3.9 \pm 0.4^{\mathrm{ab}}$ & $1.0 \pm 0.1^{c}$ \\
\hline TOM & $10.20 \pm 2.44^{c}$ & $63.3 \pm 1.6^{\mathrm{a}}$ & $22.1 \pm 0.4^{\mathrm{abc}}$ & $7.2 \pm 0.5^{b c}$ & $7.5 \pm 1.5^{b c}$ & $3.8 \pm 0.7^{b c}$ & $1.2 \pm 0.4^{\mathrm{abc}}$ & $1.3 \pm 0.2^{\mathrm{b}}$ & $5.3 \pm 0.6^{\mathrm{a}}$ & $1.4 \pm 0.2^{\mathrm{bc}}$ \\
\hline Filamentous algae & $9.85 \pm 4.23^{c}$ & $52.6 \pm 1.3^{a}$ & $32.7 \pm 2.7^{a}$ & $5.7 \pm 1.1^{c}$ & $9.1 \pm 0.6^{\mathrm{abc}}$ & $6.1 \pm 0.2^{\mathrm{abc}}$ & $0.3 \pm 0.2^{d}$ & $1.8 \pm 0.3^{\mathrm{ab}}$ & $4.3 \pm 1.5^{\mathrm{ab}}$ & $1.6 \pm 1.0^{\mathrm{abc}}$ \\
\hline Sediment & $5.68 \pm 2.43^{c}$ & $59.6 \pm 1.2^{\mathrm{a}}$ & $25.5 \pm 0.7^{\mathrm{ab}}$ & $7.3 \pm 0.7 b c$ & $7.7 \pm 0.9^{\mathrm{bc}}$ & $4.3 \pm 0.6^{b c}$ & $0.6 \pm 0.1^{c d}$ & $1.6 \pm 0.2^{\mathrm{ab}}$ & $4.2 \pm 0.3^{\mathrm{ab}}$ & $1.2 \pm 0.2^{\mathrm{bc}}$ \\
\hline
\end{tabular}


720 Figure 1: Map of the study area. The Płociczna flows through a series of lakes before its confluence with the Drawa, and both wood-poor and wood-rich sampling locations were located $700 \mathrm{~m}-1 \mathrm{~km}$ downriver of the outlet of Lake Sitno.

Figure 2: Non-metric multidimensional scaling of the macroinvertebrate assemblage composition in the three sampled substrates (WW: wood surface in the wood-rich site; WS: river-bed sediment surrounding wood in the wood-rich site; NW: river-bed sediment in the wood-poor site), performed on $\log (\mathrm{x}+1)$-transformed abundances and with Bray-Curtis distance.

Figure 3: Stable carbon and nitrogen isotope signatures of resources (lines, mean \pm s.d.) and macroinvertebrates (circles) in the wood-poor site (NW, dotted lines and open circles) and in the wood-rich site (W, solid lines and solid circles). The isotopic signatures of macroinvertebrates were corrected by trophic enrichment factors of $0.4 \pm 1.3 \%$ for $\delta^{13} \mathrm{C}$ and $3.4 \pm 1.0 \%$ for $\delta^{15} \mathrm{~N}$ (Post, 2002); those values were doubled for predator taxa. Resources abbreviations: FilA= filamentous algae; Bry= bryophytes; $\mathrm{TOM}=$ transported organic matter; $\mathrm{SM}=$ seston inferred from the isotopic signature of unionid mussels (see text for explanation); PeriW= periphyton on wood; PeriM= periphyton on the shells of unionid mussels; $D=$ detritus; $W=$ wood; $G=$ grass; $L=$ leaves.

Figure 4: Contributions of the trophic resources to the total biomass of the macroinvertebrate assemblage on the three substrates (WW: wood surface in the wood-rich site; WS: river-bed sediment surrounding wood in the wood-rich site; NW: river-bed sediment in the wood-poor site). Mean values $\pm 95 \%$ credible interval. Only the three groups of food resources which contributed the most to macroinvertebrate biomass are shown: SesM-FilA= seston inferred from Unionids (see text for explanation) and filamentous algae, PeriW-Bry= periphyton on wood and bryophytes, $\mathrm{Gr}-\mathrm{L}=$ grass and leaves.

Figure 5: Non-metric dimensional scaling of all basal resources and collected macroinvertebrates in the study locations. Ellipses represent 95\% confidence intervals around the centroid for each basal resource. Ordispider lines are used for filamentous algae (Fil A) and transported organic matter (TOM) to indicate high variability in the samples. Consumer values (symbol) represent the centroid and 1 standard error, and consumer proximity with food resources indicate feeding preferences. All consumers are grouped by order in the figure to aid interpretation of the figure, except for Sphaeriidae and D. polymorpha. Glossiphoniidae is outside of viewable chart area. WW (wood surface in the wood-rich site; black fill), WS (river-bed sediments surrounding the wood; grey fill), and NW (river- bed sediment in the wood-poor site; white fill). Bry = bryophytes. PeriM = periphyton on the shells of unionid mussels. PeriW = periphyton on the surface of wood. $\mathrm{Gr}=$ 


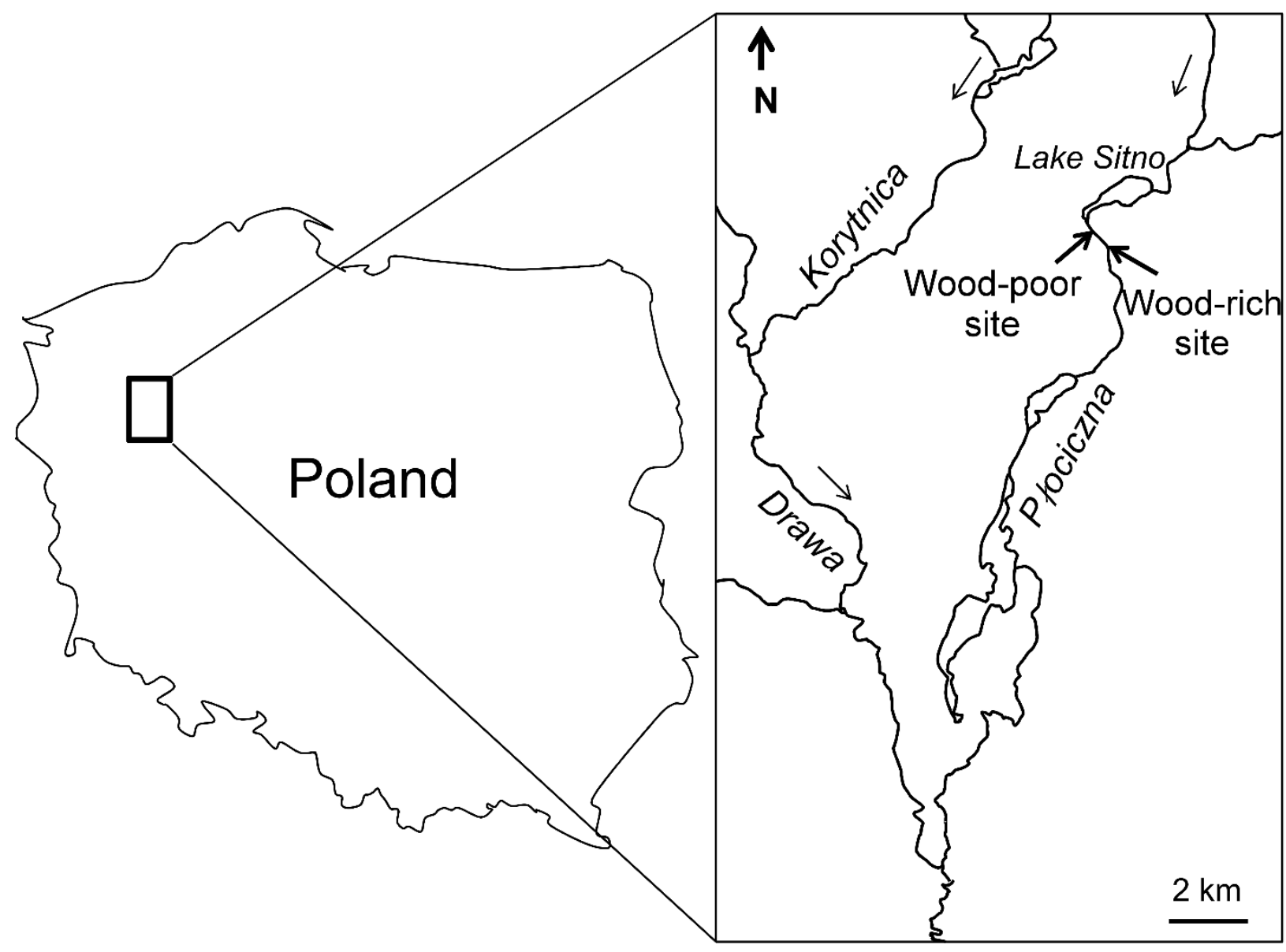

755

756 Figure 1 


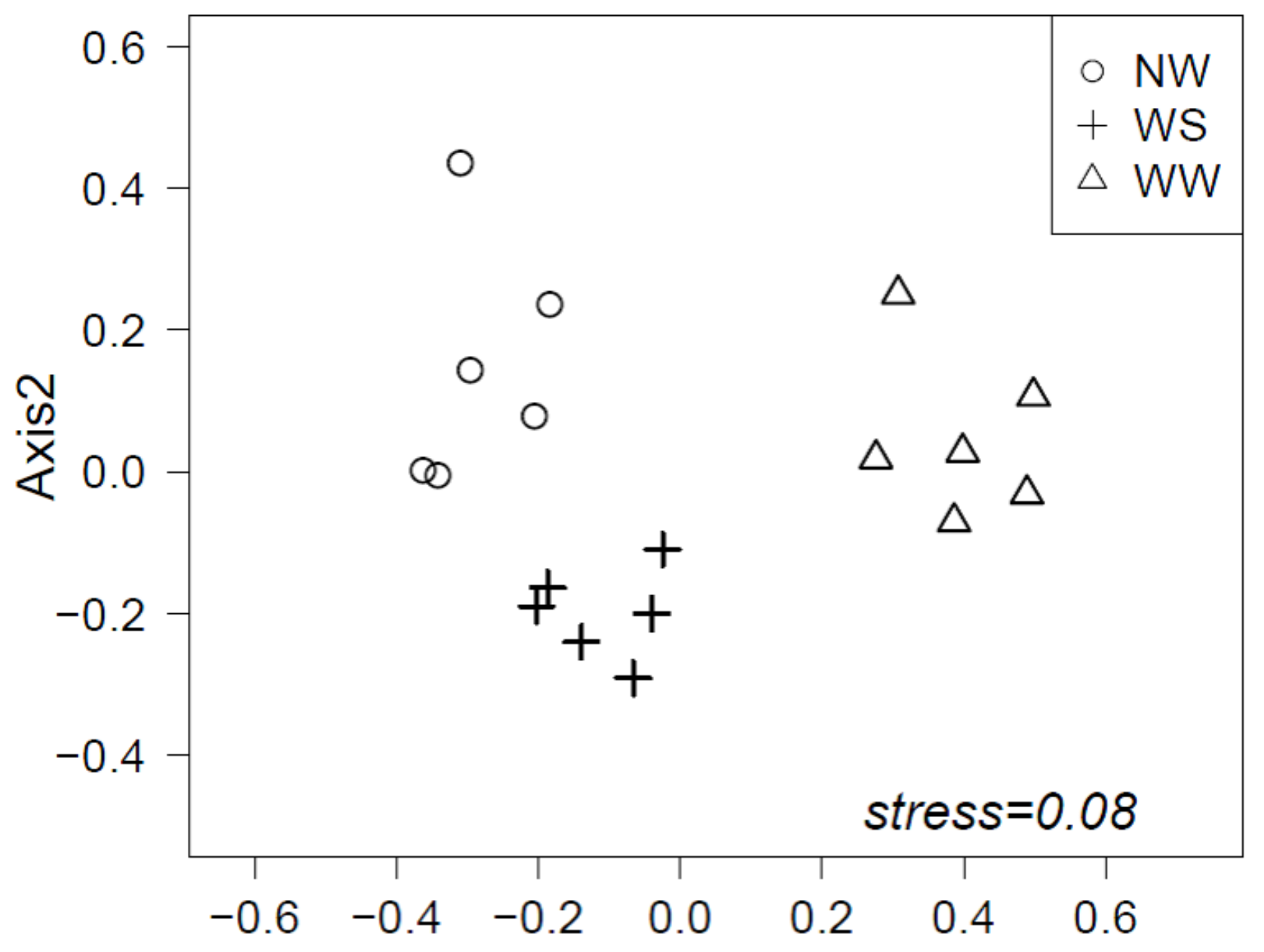

757

Axis1

$758 \quad$ Figure 2

759 


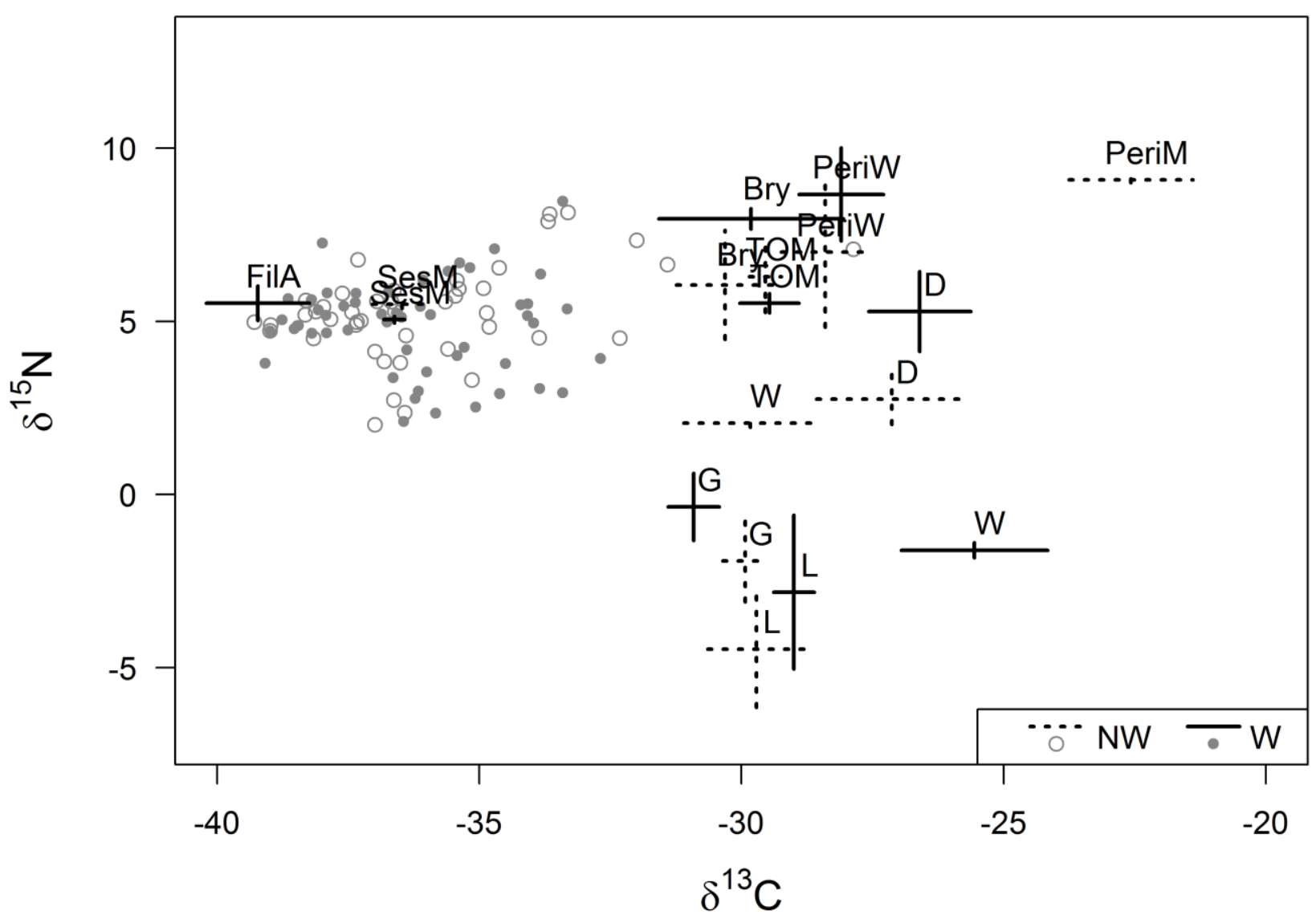

760

Figure 3

762 


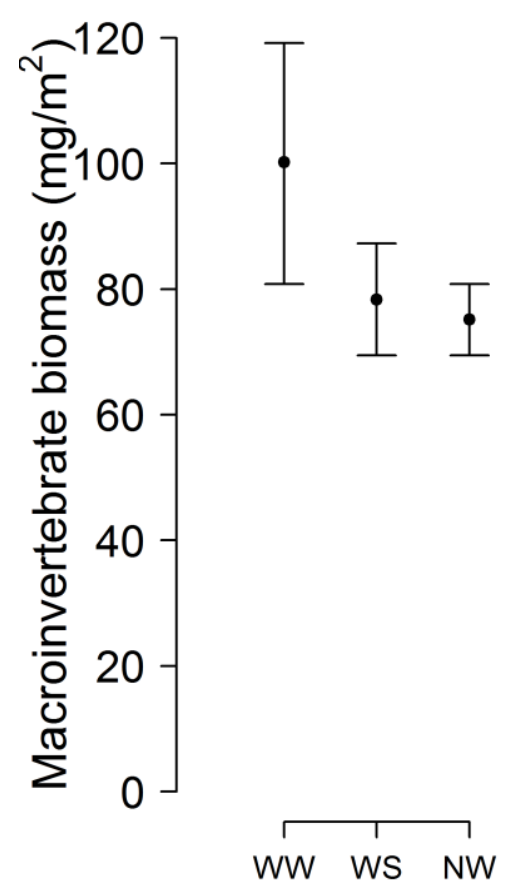

763

764

765

Figure 4

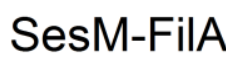

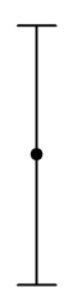
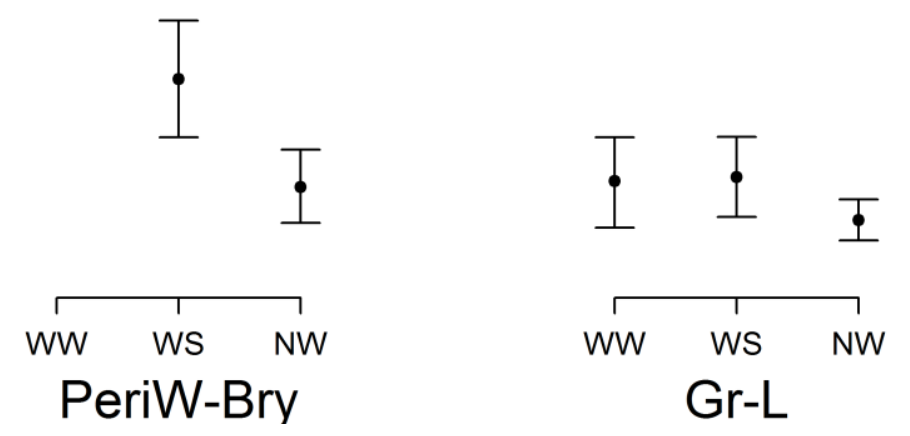

PeriW-Bry

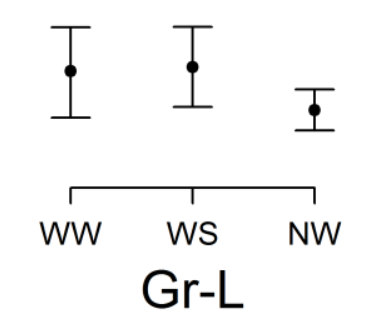




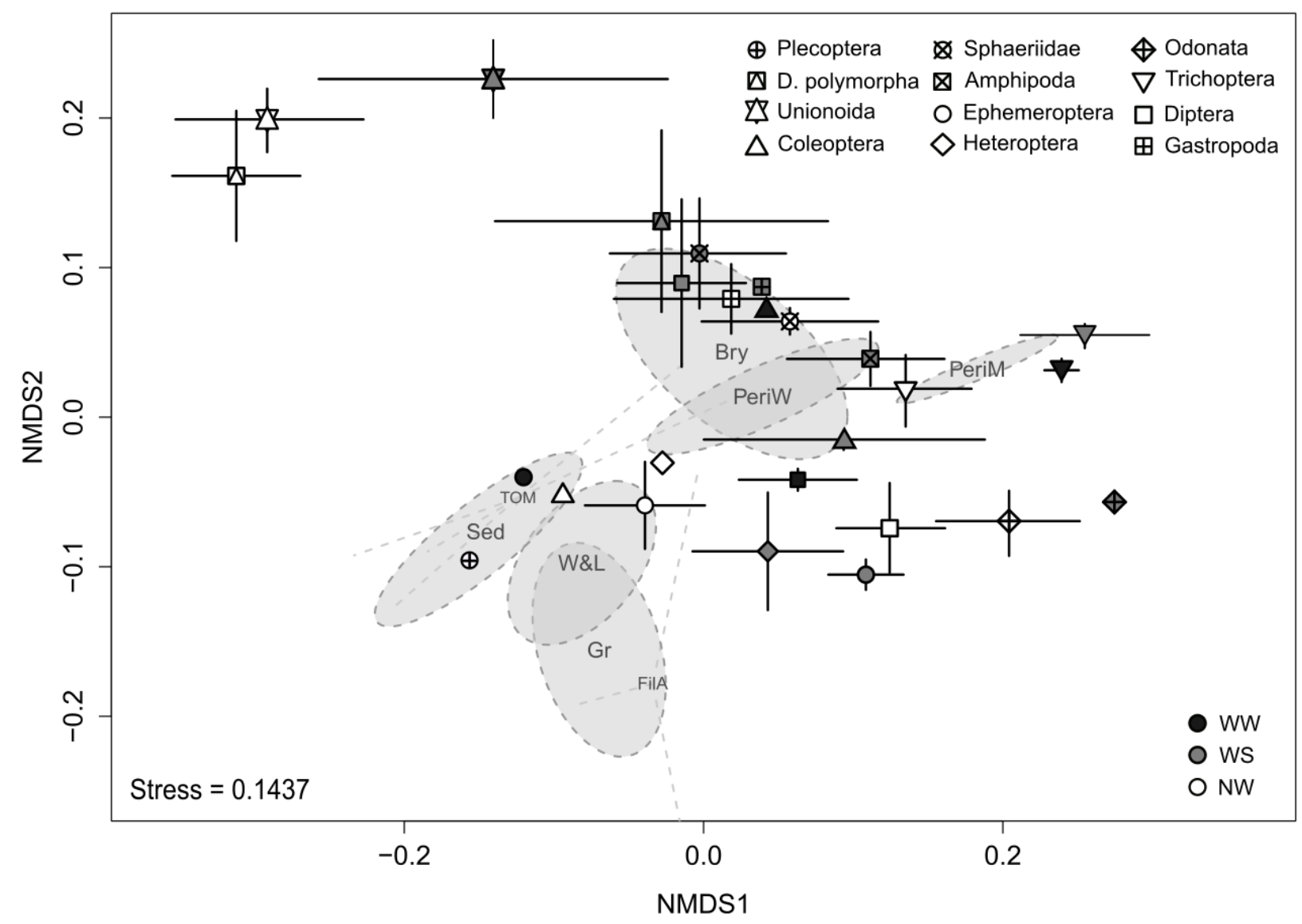

766

Figure 5 


\section{Appendices (Supporting Information)}
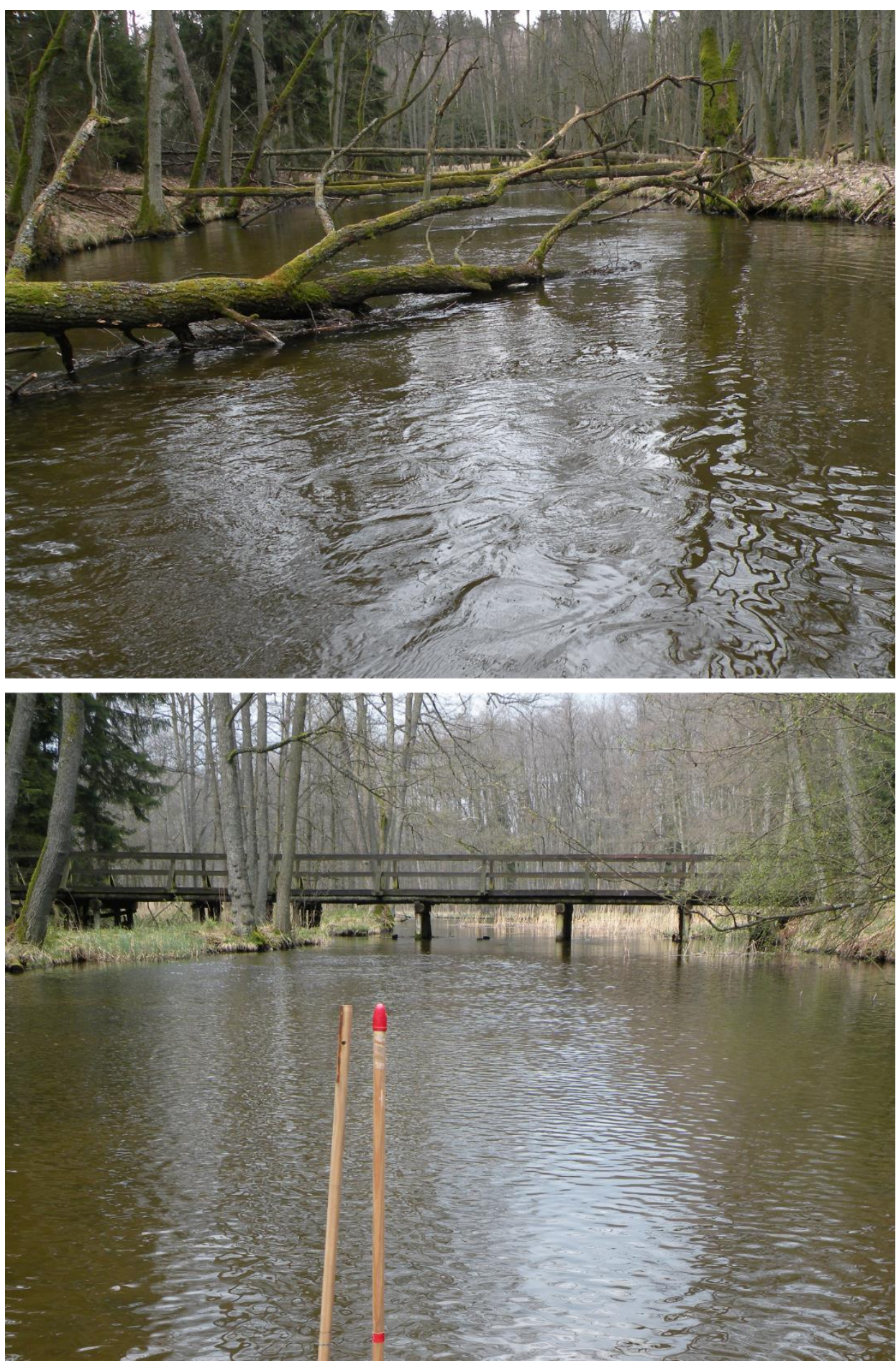

Figure S1: Pictures taken in both the wood-rich (top) and wood-poor (bottom) sites in the Płociczna River looking downriver from mid-channel. Each site was a $100 \mathrm{~m}$ long reach, and 300 $\mathrm{m}$ separated the two sites. Macroinvertebrates were sampled in the wood-rich site on the wood surface (WW) and in sediment surrounding wood (WS), and in the wood-poor site in river-bed sediment (NW). 


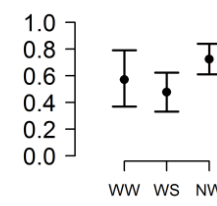

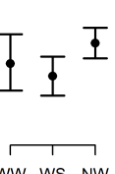
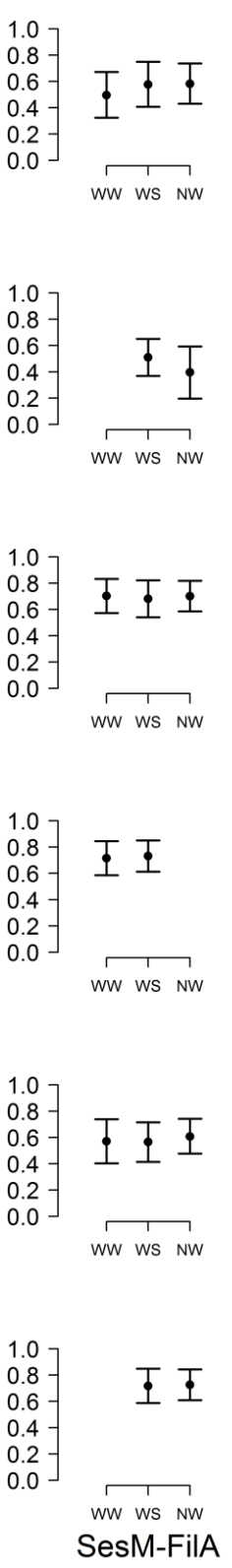
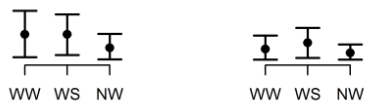

C

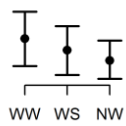

호포

WW WS NW

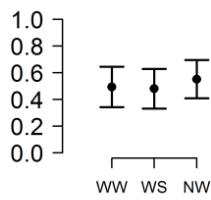

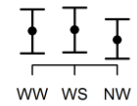

호호 호

WW WS NW

D

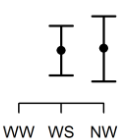

E

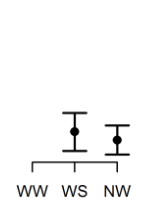

$$
\left.\begin{array}{l}
1.0 \\
0.8 \\
0.6 \\
0.4 \\
0.2 \\
0.0
\end{array}\right]
$$

$\Phi \Phi$

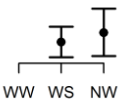

G

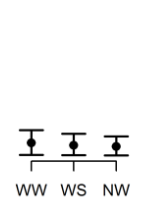

$$
\left.\begin{array}{l}
1.0 \\
0.8 \\
0.6 \\
0.4 \\
0.2 \\
0.0
\end{array}\right]
$$

I
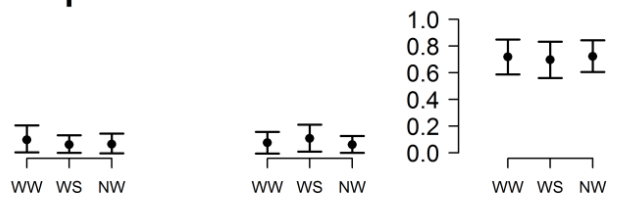

K

Figure S2: Relative contributions of the basal trophic resources to the diet of collected macroinvertebrates in the three sampling substrates (WW: wood surface; WS: river-bed sediments surrounding the wood; NW: river-bed sediment in the wood-poor site) according to the result of the isotopic mixing model (see text for details). Mean values $\pm 95 \%$ credible interval. Figure only shows results obtained for taxa collected in both wood and non-wood sites, and only displays trophic resources which contributed $>10 \%$ to the diet of at least one taxon. SesM-FilA $=$ seston inferred from Unionids (see text for explanation) and filamentous algae, PeriW-Bry= periphyton on wood and bryophytes, Gr-L= grass and leaves. A: Chironomidae, B: Caenis sp., C: Ephemera danica, D: Oligochaeta, E: Bithynia tentaculata, F: Gomphidae, G: Sphaeriidae, H: Hydropsychae sp., I: Orectochilus villosus, L: Policentropodidae, M: Aphelocheirus aestivalis, N: Tabanidae, O: Dreissena polymorpha, P: Baetis sp. 
Table S1: Fatty acid composition data for all consumers. Values indicate percentage mean and standard error. SAFA $=$ saturated fatty acids.

MUFA = monounsaturated fatty acids. PUFA = polyunsaturated fatty acids. HUFA = highly unsaturated fatty acids. EPA = eicosapentaenoic acid;

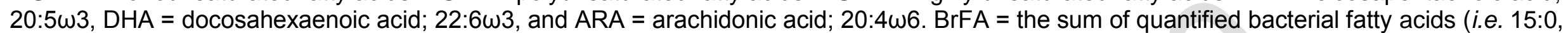
17:0). $\omega 3: \omega 6=$ the ratio of the sum of all omega-3 to omega- 6 fatty acids. Letters indicate post-hoc significant differences between sampling substrates at $P<0.05$.

\begin{tabular}{|c|c|c|c|c|c|c|c|c|c|c|c|}
\hline \multicolumn{2}{|l|}{ Group } & $\mathrm{N}$ & SAFA\% & MUFA\% & PUFA\% & HUFA\% & EPA\% & DHA\% & ARA $\%$ & $\omega 3: \omega 6$ & BrFA \\
\hline \multicolumn{2}{|c|}{ A. aestivalis adult } & 2 & $43.5 \pm 4.1$ & $21.1 \pm 4.4$ & $15.2 \pm 0.1$ & $20.3 \pm 0.5$ & $13.1 \pm 0.4$ & $0.9 \pm 0.5$ & $4.2 \pm 0.4$ & $1.4 \pm 0.1$ & $2.3 \pm 0.2$ \\
\hline \multicolumn{2}{|c|}{ A. aestivalis larvae } & 3 & $61.3 \pm 6.7$ & $18.3 \pm 4.6$ & $9.3 \pm 1.1$ & $11.0 \pm 1.0$ & $7.3 \pm 0.6$ & $0.3 \pm 0.2$ & $2.0 \pm 0.2$ & $1.4 \pm 0.1$ & $2.9 \pm 0.7$ \\
\hline \multicolumn{2}{|l|}{ Baetis } & 2 & $60.3 \pm 1.2$ & $21.9 \pm 2.5$ & $8.0 \pm 0.9$ & $9.7 \pm 0.3$ & $7.5 \pm 0.3$ & $0.2 \pm 0.1$ & $1.0 \pm 0.2$ & $2.4 \pm 0.4$ & $4.1 \pm 0.0$ \\
\hline \multicolumn{2}{|l|}{ Bithynia } & 3 & $53.4 \pm 0.4$ & $14.0 \pm 2.2$ & $9.8 \pm 0.8$ & $22.8 \pm 1.7$ & $9.8 \pm 1.6$ & $5.3 \pm 1.0$ & $4.8 \pm 0.5$ & $2.2 \pm 0.4$ & $3.4 \pm 0.5$ \\
\hline \multicolumn{2}{|l|}{ Caenis } & 3 & $51.0 \pm 4.7$ & $22.8 \pm 0.6$ & $9.9 \pm 1.1$ & $16.3 \pm 4.1$ & $10.3 \pm 2.4$ & $0.4 \pm 0.1$ & $3.9 \pm 1.6$ & $1.3 \pm 0.1$ & $3.8 \pm 0.1$ \\
\hline \multirow[t]{3}{*}{ Chironomidae } & NW & 3 & $46.4 \pm 2.5$ & $23.8 \pm 0.2$ & $14.8 \pm 1.4$ & $15.0 \pm 1.0$ & $11.4 \pm 0.8^{a}$ & $0.6 \pm 0.2$ & $1.7 \pm 0.3$ & $1.7 \pm 0.2$ & $1.4 \pm 0.5^{a}$ \\
\hline & WS & 3 & $55.0 \pm 0.1$ & $18.0 \pm 2.1$ & $10.3 \pm 1.3$ & $16.7 \pm 3.0$ & $6.6 \pm 0.7^{b}$ & $3.9 \pm 2.1$ & $4.1 \pm 1.3$ & $1.5 \pm 0.4$ & $5.0 \pm 0.7^{b}$ \\
\hline & WW & 3 & $52.7 \pm 2.7$ & $18.5 \pm 3.1$ & $13.0 \pm 0.1$ & $15.9 \pm 1.7$ & $11.8 \pm 1.4^{a}$ & $0.9 \pm 0.2$ & $1.7 \pm 0.1$ & $1.7 \pm 0.2$ & $2.8 \pm 0.3^{a b}$ \\
\hline \multicolumn{2}{|l|}{ Dreissena } & 5 & $60.2 \pm 11.0$ & $23.2 \pm 11.1$ & $4.6 \pm 2.0$ & $11.8 \pm 2.5$ & $3.6 \pm 1.8$ & $3.1 \pm 0.9$ & $1.5 \pm 0.5$ & $2.1 \pm 0.5$ & $3.2 \pm 0.5$ \\
\hline \multicolumn{2}{|l|}{ Ephemera } & 5 & $51.5 \pm 2.6$ & $20.5 \pm 1.9$ & $10.0 \pm 0.9$ & $18.1 \pm 2.1$ & $12.4 \pm 1.9$ & $0.9 \pm 0.3$ & $3.2 \pm 0.2$ & $2.0 \pm 0.2$ & $3.4 \pm 0.4$ \\
\hline \multicolumn{2}{|l|}{ Gammarus } & 2 & $51.4 \pm 1.8$ & $15.9 \pm 2.2$ & $11.8 \pm 0.7$ & $20.9 \pm 0.3$ & $12.5 \pm 1.0$ & $3.0 \pm 0.8$ & $2.7 \pm 0.8$ & $2.6 \pm 0.5$ & $3.2 \pm 0.7$ \\
\hline \multicolumn{2}{|l|}{ Glossiphonia } & 1 & 22.1 & 22.4 & 6.2 & 49.3 & 10.9 & 2.9 & 26.2 & 0.6 & 2.0 \\
\hline \multicolumn{2}{|l|}{ Gomphidae } & 4 & $51.2 \pm 0.9$ & $10.2 \pm 2.4$ & $16.8 \pm 1.5$ & $21.8 \pm 0.7$ & $16.3 \pm 0.9$ & $1.3 \pm 0.2$ & $2.9 \pm 0.1$ & $2.6 \pm 0.1$ & $1.5 \pm 0.2$ \\
\hline \multirow[t]{3}{*}{ Hydropsyche } & NW & 3 & $57.7 \pm 1.8^{a}$ & $17.7 \pm 2.0$ & $10.2 \pm 0.4^{a}$ & $14.4 \pm 0.6^{a}$ & $9.7 \pm 0.2^{a}$ & $1.4 \pm 0.3^{a}$ & $1.5 \pm 0.1$ & $2.9 \pm 0.1^{a}$ & $4.2 \pm 1.0^{a}$ \\
\hline & WS & 6 & $50.8 \pm 1.7^{b}$ & $14.6 \pm 1.2$ & $12.4 \pm 0.7^{b}$ & $22.3 \pm 1.1^{b}$ & $13.8 \pm 0.6^{b}$ & $3.2 \pm 0.2^{b}$ & $1.8 \pm 0.1$ & $3.8 \pm 0.1^{b}$ & $3.0 \pm 0.6^{a}$ \\
\hline & WW & 7 & $50.2 \pm 1.1^{\mathrm{b}}$ & $15.4 \pm 1.2$ & $12.6 \pm 0.3^{b}$ & $21.8 \pm 0.8^{b}$ & $14.6 \pm 0.6^{b}$ & $2.4 \pm 0.2^{c}$ & $1.7 \pm 0.1$ & $3.8 \pm 0.1^{b}$ & $2.6 \pm 0.4^{a}$ \\
\hline & 1 & 59.1 & 25.7 & 8.6 & 6.6 & 3.5 & 0.5 & 1.5 & 0.8 & 5.7 \\
\hline \multicolumn{2}{|l|}{ Orectochilus } & 4 & $50.4 \pm 3.9$ & $22.4 \pm 2.4$ & $12.6 \pm 1.2$ & $14.6 \pm 2.8$ & $9.8 \pm 2.1$ & $1.0 \pm 0.3$ & $1.2 \pm 0.2$ & $2.8 \pm 0.4$ & $2.8 \pm 0.3$ \\
\hline \multicolumn{2}{|l|}{ Platycnemis } & 1 & 55.5 & 14.9 & 12.6 & 17.0 & 12.4 & 0.4 & 3.3 & 1.6 & 3.2 \\
\hline \multicolumn{2}{|c|}{ Polycentropodidae } & 2 & $48.1 \pm 1.1$ & $15.2 \pm 7.4$ & $13.1 \pm 0.3$ & $23.6 \pm 6.1$ & $14.3 \pm 2.4$ & $4.2 \pm 3.0$ & $1.8 \pm 0.2$ & $3.7 \pm 1.2$ & $2.0 \pm 0.1$ \\
\hline \multicolumn{2}{|c|}{ Potamopyrgus } & 1 & 59.7 & 19.8 & 7.3 & 13.3 & 5.0 & 2.2 & 3.7 & 1.3 & 3.9 \\
\hline \multicolumn{2}{|l|}{ Sphaerium } & 5 & $52.6 \pm 2.9$ & $19.4 \pm 1.5$ & $10.5 \pm 1.3$ & $17.5 \pm 2.1$ & $6.6 \pm 1.4$ & $4.5 \pm 0.6$ & $3.9 \pm 0.6$ & $1.7 \pm 0.2$ & $4.0 \pm 0.6$ \\
\hline \multicolumn{2}{|l|}{ Tabanidae } & 1 & 59.8 & 21.5 & 7.6 & 11.2 & 5.8 & 1.9 & 1.9 & 1.9 & 4.8 \\
\hline \multicolumn{2}{|l|}{ Unionidae } & 10 & $64.5 \pm 6.0$ & $13.6 \pm 1.6$ & $5.6 \pm 1.1$ & $16.3 \pm 3.5$ & $4.5 \pm 1.6$ & $2.6 \pm 0.9$ & $5.3 \pm 1.7$ & $0.7 \pm 0.1$ & $5.0 \pm 0.3$ \\
\hline
\end{tabular}

